\title{
Monazite trumps zircon: applying SHRIMP U-Pb geochronology to systematically evaluate emplacement ages of leucocratic, low-temperature granites in a complex Precambrian orogen
}

\author{
Agnieszka M. Piechocka ${ }^{1}\left(\mathbb{D} \cdot\right.$ Courtney J. Gregory ${ }^{1} \cdot$ Jian-Wei $\mathbf{Z i}^{1} \cdot$ \\ Stephen Sheppard $^{1} \cdot$ Michael T. D. Wingate $^{2} \cdot$ Birger Rasmussen $^{1}$
}

Received: 13 January 2017 / Accepted: 24 June 2017 / Published online: 7 July 2017

(C) The Author(s) 2017. This article is an open access publication

\begin{abstract}
Although zircon is the most widely used geochronometer to determine the crystallisation ages of granites, it can be unreliable for low-temperature melts because they may not crystallise new zircon. For leucocratic granites U-Pb zircon dates, therefore, may reflect the ages of the source rocks rather than the igneous crystallisation age. In the Proterozoic Capricorn Orogen of Western Australia, leucocratic granites are associated with several pulses of intracontinental magmatism spanning $\sim 800$ million years. In several instances, SHRIMP
\end{abstract}

Communicated by Franck Poitrasson.

The original version of this article was revised: Figures 1 and 2 were incorrect and they have been corrected.

Electronic supplementary material The online version of this article (doi:10.1007/s00410-017-1386-5) contains supplementary material, which is available to authorized users.

Agnieszka M. Piechocka

nishka.piechocka@postgrad.curtin.edu.au

Courtney J. Gregory

courtneyjaynegregory@gmail.com

Jian-Wei Zi

j.zi@curtin.edu.au

Stephen Sheppard

stephen.sheppard@curtin.edu.au

Michael T. D. Wingate

michael.wingate@dmp.wa.gov.au

Birger Rasmussen

b.rasmussen@curtin.edu.au

1 Department of Applied Geology, Curtin University, Kent Street, Bentley, WA 6102, Australia

2 Geological Survey of Western Australia, 100 Plain Street, East Perth, WA 6004, Australia
$\mathrm{U}-\mathrm{Pb}$ zircon dating of these leucocratic granites either yielded ages that were inconclusive (e.g., multiple concordant ages) or incompatible with other geochronological data. To overcome this we used SHRIMP U-Th- $\mathrm{Pb}$ monazite geochronology to obtain igneous crystallisation ages that are consistent with the geological and geochronological framework of the orogen. The U-Th-Pb monazite geochronology has resolved the time interval over which two granitic supersuites were emplaced; a Paleoproterozoic supersuite thought to span $\sim 80$ million years was emplaced in less than half that time $(1688-1659 \mathrm{Ma})$ and a small Meso- to Neoproterozoic supersuite considered to have been intruded over $\sim 70$ million years was instead assembled over 130 million years and outlasted associated regional metamorphism by $\sim 100$ million years. Both findings have consequences for the duration of associated orogenic events and any estimates for magma generation rates. The monazite geochronology has contributed to a more reliable tectonic history for a complex, long-lived orogen. Our results emphasise the benefit of monazite as a geochronometer for leucocratic granites derived by low-temperature crustal melting and are relevant to other orogens worldwide.

Keywords Monazite - SHRIMP geochronology · Leucocratic granite $\cdot$ Pegmatite $\cdot$ Proterozoic $\cdot$ Capricorn Orogen

\section{Introduction}

Leucocratic granites are peraluminous [i.e., alumina saturation index $(\mathrm{ASI})=$ molar $\mathrm{Al}_{2} \mathrm{O}_{3} /\left(\mathrm{CaO}+\mathrm{Na}_{2} \mathrm{O}+\mathrm{K}_{2} \mathrm{O}\right)>1$; Scaillet et al. 2016; Zen 1986] rocks containing <5 vol.\% mafic minerals (Le Maitre 1989). They are typically derived from low-temperature $\left(<750{ }^{\circ} \mathrm{C}\right.$; Ayres et al. 1997; Scaillet et al. 1995) partial melting of crustal sources without direct 
mass input from the mantle (Gao et al. 2017; Patiño and Harris 1998). Leucocratic granites are common in intracontinental and collisional settings and typically account for a small proportion of all granites in orogenic belts (Gilotti and McClelland 2005; Harrison et al. 1999; Kemp and Hawkesworth 2003). However, they are important for determining the tectonic history of orogenic belts (Crowley et al. 2008) as they commonly form during periods of crustal thickening (Brown 1994). Kemp and Hawkesworth (2003) divided leucocratic granites into two types on the basis of their $\mathrm{Sr}$ concentrations: a low-Sr (<200 ppm Sr) type formed by melting in the upper continental crust (e.g., leucogranites of the Himalayan Orogen), and the less common high-Sr (250-450 ppm) types related to deeper crustal sources (e.g., Glenelg River Complex, southeastern Australia).

Dating leucocratic, low-temperature granites (sensu lato) using $\mathrm{U}-\mathrm{Pb}$ zircon geochronology can be challenging due to the zircon population being dominated by inherited grains (Bea et al. 2007; Harrison et al. 1999; Miller et al. 2003; Schärer et al. 1986). Experimental studies have shown that zircon solubility is mainly governed by temperature and melt composition, and for typical peraluminous melts zircon solubility ranges from $\sim 100 \mathrm{ppm}$ dissolved at $750{ }^{\circ} \mathrm{C}$ to $1300 \mathrm{ppm}$ at $1020^{\circ} \mathrm{C}$ (Boehnke et al. 2013; Watson and Harrison 1983). This means that the low solubility of $\mathrm{Zr}$ in low-temperature $\left(<800{ }^{\circ} \mathrm{C}\right)$ crustal melts limits the amount of zircon that can dissolve during partial melting and re-precipitate during crystallisation. These findings are consistent with observations that low-temperature granites (mean $766 \pm 24^{\circ} \mathrm{C}$ ) with abundant inherited zircon typically have lower $\mathrm{Zr}$ concentrations (80-150 ppm) compared with high-temperature granites (200-800 ppm, mean $837 \pm 48^{\circ} \mathrm{C}$ ) with minimal inheritance (Miller et al. 2003).

Although zircon is most widely used to constrain crystallisation ages of granites, monazite geochronology has been employed sporadically to date the crystallisation age of granites (e.g., Grosse et al. 2009; Harrison et al. 1999; Kusiak et al. 2014; Miller and Mittlefehldt 1982; Parrish and Tirrul 1989; Townsend et al. 2001; Williams et al. 1983). However, there has been little attempt to systematically evaluate the suitability of monazite for geochronology of leucocratic granite types even though monazite appears to be common in a range of granites (Bea 1996; Montel 1993; Rapp and Watson 1986). The stability of monazite is considered to be dependent on pressure, temperature, bulk rock chemistry and interacting fluid chemistry (Budzyń et al. 2011; Poitrasson et al. 1996). It has been suggested that monazite is stable in host compositions that are low in $\mathrm{Ca}(<0.7 \%)$ in contrast to higher $\mathrm{Ca}(>1.8 \%)$ which favour allanite growth (Lee and Dodge 1964; Montel 1993; Parrish 1990), although monazite and allanite do coexist in peraluminous granites (Broska et al. 2000). Furthermore, although not widespread, instances of monazite inheritance in granites have been documented (Copeland et al. 1988; Parrish 1990).

Leucocratic granites are widespread in the Proterozoic Gascoyne Province, Capricorn Orogen of Western Australia, and apparently formed during several episodes of magmatism (Sheppard et al. 2010b). The crystallisation ages of several leucocratic granites are not well defined by $\mathrm{U}-\mathrm{Pb}$ zircon geochronology, which has created uncertainty about the duration and distribution of some of the granite supersuites and related orogenic events in the province. In this paper we use SHRIMP U-Th-Pb monazite geochronology to re-evaluate the emplacement ages of these granites in order to obtain reliable igneous crystallisation ages consistent with the existing geological framework. In turn, this provides better constraints on the duration of granitic magmatism and magma production rates and allows for a more complete magmatic and tectonothermal history of the orogen to be established.

\section{Regional geology}

The study area is located in the Capricorn Orogen in Western Australia (Fig. 1), which records the Paleoproterozoic assembly of the West Australian Craton by c. $1950 \mathrm{Ma}$ (Johnson et al. 2011; Occhipinti et al. 2004). Five subsequent, episodic intracontinental reworking and reactivation events spanning nearly 1.5 billion years have shaped the current architecture of this orogen (Bodorkos and Wingate 2007; Korhonen et al. 2015; Sheppard et al. 2005, 2007, 2010a). All of these tectonic events are known from the Gascoyne Province, at the presently exposed western end of the orogen (Fig. 1). Of the five intracontinental reworking events in the Gascoyne Province, two are accompanied by voluminous, mainly high-temperature granitic magmatism (i.e., the Capricorn Orogeny being associated with the 1820-1775 Ma Moorarie Supersuite, and the Mangaroon Orogeny with the 1680-1620 Ma Durlacher Supersuite), whereas a third, spatially restricted event (the Edmundian Orogeny) was accompanied solely by leucocratic granitic magmatism (995-955 Ma Thirty-Three Supersuite) (Sheppard et al. 2010b).

The 1820-1775 Ma Moorarie Supersuite was emplaced during the Capricorn Orogeny (Sheppard et al. 2010a, b) and comprises batholiths and plutons of weakly peraluminous, biotite-bearing monzogranite and granodiorite, with minor syenogranite, tonalite and quartz diorite, although, biotite (-muscovite-tourmaline)-bearing monzogranite is common in the southern Gascoyne Province. Most granites of the Moorarie Supersuite contain little or no xenocrystic zircon so that their igneous crystallisation ages are well constrained. A number of undated plutons have also been assigned to the supersuite on the basis of their field 

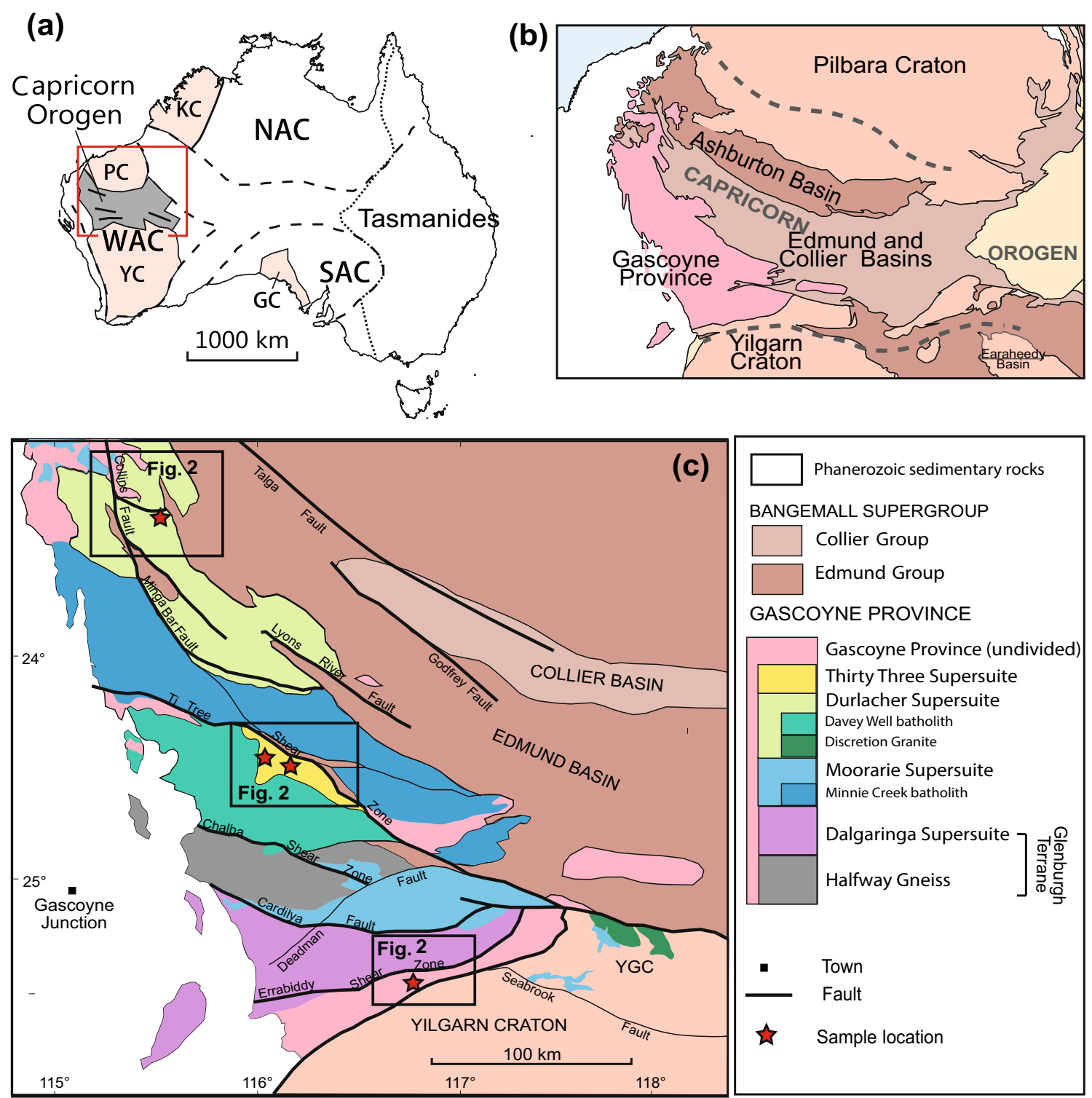

Fig. 1 Regional geological setting of the Capricorn Orogen in relation to Australia (a) and (b) and simplified regional geology of the Gascoyne Province showing discrete fault- bounded E-W trending domains (c). Outlines of study areas are presented in more detail in
Fig. 2. $P C$ Pilbara Craton, $Y C$ Yilgarn Craton, WAC West Australian Craton, GC Gawler Craton, NAC North Australian Craton, SAC South Australian Craton, $Y G C$ Yarlarweelor Gneiss Complex (adapted from Johnson et al. (2017) and $\mathrm{Zi}$ et al. (2015)) relationships, including a pluton of leucocratic granodiorite $12 \mathrm{~km}$ long by $5 \mathrm{~km}$ wide in the Errabiddy Shear Zone, which marks the boundary between the Yilgarn Craton and Gascoyne Province (Figs. 1, 2a). The pluton, referred to as the Erong Granite, cuts across Paleoproterozoic (c. $1950 \mathrm{Ma}$ ) migmatitic structures in surrounding metamorphic rocks (Occhipinti et al. 2001). However, previous SHRIMP U-Pb zircon dating of the granodiorite (GSWA 139466) only yielded an Archean maximum crystallisation age (Nelson 2000).

The 1680-1620 Ma Durlacher Supersuite comprises peraluminous biotite-muscovite monzogranite, granodiorite, and syenogranite and some leucocratic muscovite-tourmaline (-biotite) monzogranite (Sheppard et al. 2005, 2010b). Crystallisation ages of the Durlacher Supersuite granites are well constrained by U-Pb zircon geochronology and most granites are older than c. 1659 Ma (Sheppard et al. 2010b) with two main exceptions: the c. 1620 Ma Discretion Granite (Nelson 1998) and one leucocratic sample (Fig. 2b) from the northern Gascoyne Province (GSWA 169092). This leucocratic granite (GSWA 169092) yielded two concordant ages 60 million years apart, none of which could be interpreted unequivocally as the crystallisation age. The younger age component is within error of the 


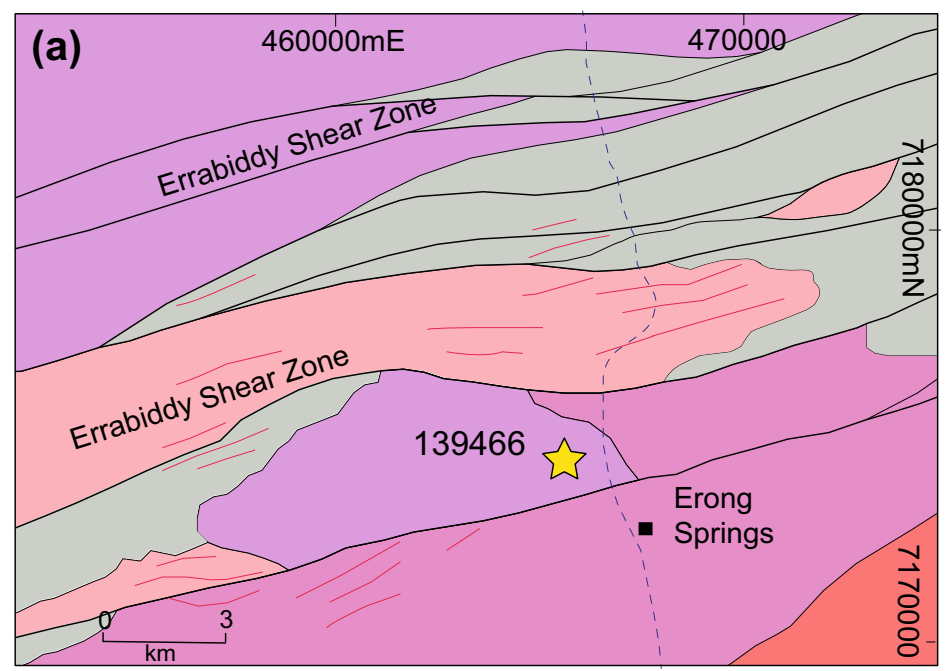

\begin{tabular}{|c|c|}
\hline NEO & PROTEROZOIC \\
\hline & $\begin{array}{l}\text { Thirty Three Supersuite } \\
\text { (995-955 Ma) }\end{array}$ \\
\hline MES & SOPROTEROZOIC \\
\hline & $\begin{array}{l}\text { Edmund Group } \\
(1620-1450 \mathrm{Ma})\end{array}$ \\
\hline PALE & EOPROTEROZOIC \\
\hline & $\begin{array}{l}\text { Durlacher Supersuite } \\
\quad(1680-1620 \mathrm{Ma})\end{array}$ \\
\hline & $\begin{array}{l}\text { Pooranoo Metamorphics } \\
\text { (1760-1680 Ma) }\end{array}$ \\
\hline & $\begin{array}{c}\text { Moorarie Supersuite } \\
\quad(1820-1775 \mathrm{Ma})\end{array}$ \\
\hline & $\begin{array}{l}\text { Leake Springs Metamorphics } \\
\quad(1840-1810 \mathrm{Ma})\end{array}$ \\
\hline & $\begin{array}{l}\text { Bertibubba Supersuite } \\
\quad(1965-1945 \mathrm{Ma})\end{array}$ \\
\hline & $\begin{array}{l}\text { Camel Hill Metamorphics } \\
\text { (2001-1955 Ma) }\end{array}$ \\
\hline $\mathrm{ARCr}$ & HEAN \\
\hline & Halfway Gneiss \\
\hline & Warrigal Gneiss \\
\hline & Narryer Terrane \\
\hline$\vec{s}$ & Samples (this study) \\
\hline 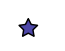 & Samples (supporting) \\
\hline$\ldots$ & Track \\
\hline$\overline{-}$ & Fault/Shear Zone \\
\hline+ & Fold axis syncline \\
\hline+ & Fold axis anticline \\
\hline- & Metamorphic foliation (2000-1950 Ma) \\
\hline
\end{tabular}

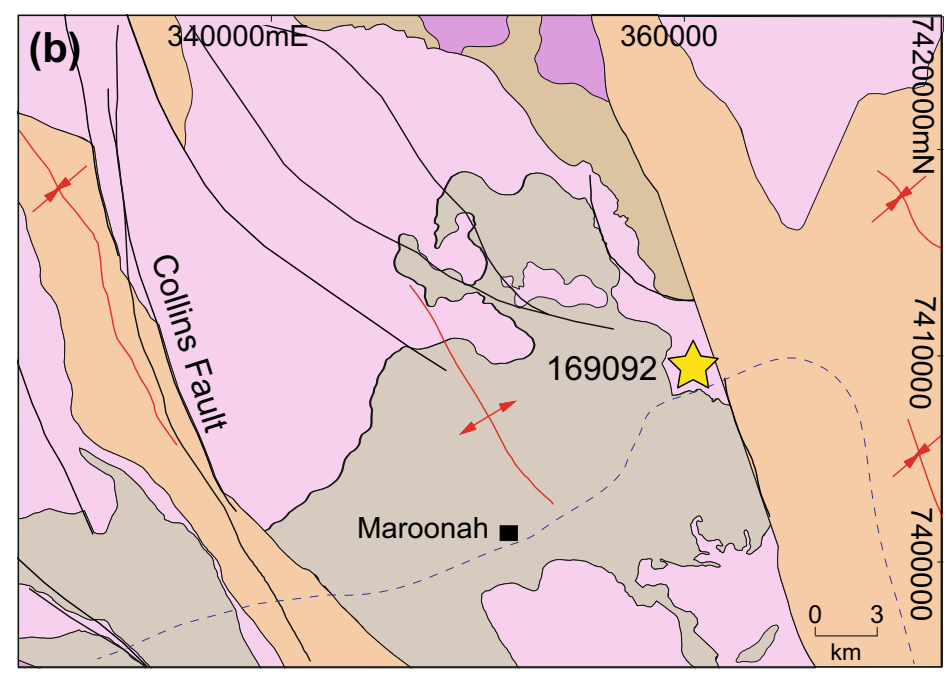

- Metamorphic foliation (2000-1950 Ma)

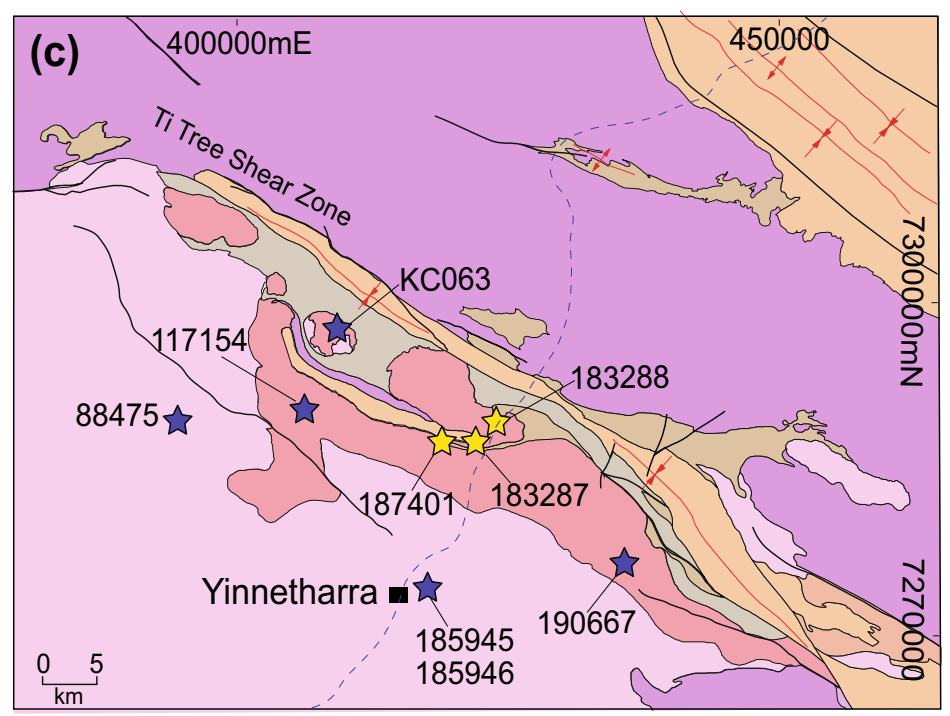


4Fig. 2 Local geology of sample areas: a the Errabiddy Shear Zone with penetrative deformation fabrics in the older granites and metasedimentary rocks; the star indicates Erong Granite sample GSWA 139466; b the northern Gascoyne Province is dominated by Proterozoic granites and folded metasedimentary rocks of the Edmund Group; the star shows the location of Red Rock Bore granite sample GSWA 169092; c The area south of the Ti Tree Shear Zone hosts the only occurrence of Thirty-Three Supersuite, in the Gascoyne Province; yellow stars indicate granite samples GSWA 183287, 183288, and 187401. Blue stars indicate supporting samples mentioned throughout the text. The ages for the metamorphic packages are depositional ages. Coordinate system in GDA 1994 MGA Zone 50. Geology polygons and linear features were extracted from the 1:500 000 Geological Map of Western Australia (GSWA 2016a)

igneous crystallisation age of c. $1620 \mathrm{Ma}$ for a batholith (Discretion Granite) about $250 \mathrm{~km}$ to the southeast (Fig. 1), and both samples were used to provide a minimum age for the Mangaroon Orogeny (Sheppard et al. 2005).

Intrusion of the 995-955 Ma Thirty-Three Supersuite (Fig. 2c) coincided with deformation and metamorphism of the Edmundian Orogeny within a narrow structural corridor in the centre of the Gascoyne Province (Sheppard et al. 2007). The supersuite crops out over an area $70 \mathrm{~km}$ long by $10 \mathrm{~km}$ wide and is structurally bound to the north by the Ti Tree Shear Zone (Fig. 2c). The Thirty-Three Supersuite comprises muscovite (-tourmaline) metamonzogranite, biotite-muscovite (-tourmaline) monzogranite and granodiorite and a belt of muscovite-tourmaline and rare-element bearing pegmatites (Sheppard et al. 2010b). Crystallisation ages for Thirty-Three Supersuite granites have proven difficult to resolve via $\mathrm{U}-\mathrm{Pb}$ zircon geochronology due to the presence of copious xenocrystic zircon. Early indications were that the granites belonged to the Paleoproterozoic Durlacher Supersuite (Culver 2001). This appeared to be consistent with the fact that the leucocratic granites and pegmatites do not intrude Mesoproterozoic sedimentary rocks of the Bangemall Supergroup within the Ti Tree Shear Zone (Fig. 2c). However, later in situ monazite geochronology showed that the granites cut metamorphic fabrics formed at 1030-990 Ma (Sheppard et al. 2007).

\section{Sample descriptions and previous zircon geochronology}

Leucocratic granite samples analysed previously using U$\mathrm{Pb}$ zircon geochronology were re-analysed in this study using $\mathrm{U}-\mathrm{Th}-\mathrm{Pb}$ monazite geochronology. Presented below are the original zircon geochronology results for selected peraluminous, leucocratic samples from three generations of Proterozoic magmatism (Table 1). The corresponding monazite geochronology is discussed in the subsequent results section.

\section{GSWA 139466}

This sample is a medium-grained, equigranular biotitemuscovite granodiorite that grades into coarser grained granite and pegmatite (Occhipinti et al. 2001). The sample contains minor muscovite and approximately 5\% total mafic minerals (biotite, garnet and epidote) (Fig. 3a). Minor sericitisation, quartz recrystallisation and biotite replacement by chlorite is evidence of a weak metamorphic overprint. The zircon crystals are equant to elongate and euhedral pale green to black, 30-250 $\mu \mathrm{m}$ long and $25-80 \mu \mathrm{m}$ wide, with only a few grains showing subtle internal zoning (Nelson 2000). U-Pb zircon geochronology yielded a date of $2621 \pm 9 \mathrm{Ma}$ (all ages in this paper are quoted with $95 \%$ uncertainties, unless indicated otherwise) (Nelson 2000). This age is interpreted to represent the age of a xenocrystic population because the pluton intruded 1965-1945 Ma granitic rocks and 2001-1955 Ma metasedimentary rocks (Sheppard et al. 2010b) and crosscuts deformation fabrics related to the 2005-1950 Ma Glenburgh Orogeny (Figs. 2a, 3a). The granodiorite is overprinted by Neoproterozoic (c. $900 \mathrm{Ma}$ ) mylonite zones (Occhipinti and Reddy 2009), but this is the only minimum constraint on its age. The low whole-rock $\mathrm{Zr}$ content (60 ppm; Table 1) is characteristic of a rock dominated by inherited zircons (Miller et al. 2003), and the combination of high $\mathrm{Sr}(369 \mathrm{ppm})$ and low $\mathrm{Rb}$ is consistent with the granite having formed by fluidfluxed melting of muscovite during crustal anatexis (Gao et al. 2017). The rare-earth elements (La, Ce and Nd) are abundant in the whole rock composition (Table 1).

\section{GSWA 169092}

This sample is from a leucocratic granite unit located in the northern Gascoyne Province where it intrudes 1840-1810 and 1760-1680 Ma metasedimentary rocks and is overlain by $1620-1450 \mathrm{Ma}$ siliciclastic rocks (Sheppard et al. 2010b) (Fig. 2b). It is a massive, medium-grained biotite-muscovite monzogranite (Figs. 3b, 4b) with minor muscovite and 5\% mafic minerals (chlorite, epidote, tourmaline and garnet). Biotite is partly replaced by chlorite, and minor sericite and undulose extinction in the quartz and recrystallised quartz are indicative of a weak metamorphic overprint. The zircon crystals are euhedral to anhedral, 100-250 $\mu \mathrm{m}$ long and 40-180 $\mu \mathrm{m}$ wide, pale brown, dark brown or black, with only a minority of grains displaying subtle zoning (Nelson 2004). Zircon geochronology yielded two age components, one at $1810 \pm 22$ and $1681 \pm 10 \mathrm{Ma}$, and one concordant analysis at $1619 \pm 15 \mathrm{Ma}(1 \sigma)$ which, at the time, was interpreted as the maximum crystallisation age (Nelson 2004) and used by Sheppard et al. (2005) to constrain the younger limits of the 1680-1620 Ma Mangaroon Orogeny. Although a recent 
Table 1 Selected whole-rock geochemistry data for leucocratic granite samples

\begin{tabular}{|c|c|c|c|c|c|}
\hline & 139466 & 169092 & 183287 & 183288 & 187401 \\
\hline & $\begin{array}{l}\text { Biotite-muscovite grano- } \\
\text { diorite }\end{array}$ & $\begin{array}{l}\text { Biotite-muscovite mon- } \\
\text { zogranite }\end{array}$ & $\begin{array}{l}\text { Muscovite-tourmaline } \\
\text { granodiorite }\end{array}$ & $\begin{array}{l}\text { Biotite-muscovite-tour- } \\
\text { maline monzogranite }\end{array}$ & $\begin{array}{l}\text { Tourmaline-muscovite } \\
\text { monzogranite }\end{array}$ \\
\hline \multicolumn{6}{|l|}{$(\mathrm{wt} \%)$} \\
\hline $\mathrm{SiO}_{2}$ & 76.84 & 73.85 & 75.51 & 73.24 & 73.19 \\
\hline $\mathrm{TiO}_{2}$ & 0.09 & 0.18 & 0.05 & 0.21 & 0.14 \\
\hline $\mathrm{Al}_{2} \mathrm{O}_{3}$ & 13.61 & 13.86 & 13.16 & 13.27 & 13.83 \\
\hline $\mathrm{Fe}_{2} \mathrm{O}_{3}^{\text {Total }}$ & 0.70 & 1.59 & 0.94 & 1.87 & 1.21 \\
\hline $\mathrm{MnO}$ & 0.02 & 0.06 & 0.04 & 0.08 & 0.02 \\
\hline $\mathrm{MgO}$ & 0.22 & 0.38 & 0.08 & 0.32 & 0.20 \\
\hline $\mathrm{CaO}$ & 1.36 & 0.81 & 0.58 & 0.86 & 0.77 \\
\hline $\mathrm{Na}_{2} \mathrm{O}$ & 4.91 & 2.86 & 2.96 & 2.77 & 3.41 \\
\hline $\mathrm{K}_{2} \mathrm{O}$ & 2.20 & 5.20 & 4.75 & 5.24 & 5.69 \\
\hline $\mathrm{P}_{2} \mathrm{O}_{5}$ & 0.05 & 0.23 & 0.22 & 0.15 & 0.10 \\
\hline LOI & -0.01 & 0.85 & 1.57 & 1.84 & 1.31 \\
\hline $\begin{array}{l}\mathrm{A} / \mathrm{CNK}^{\mathrm{a}} \\
(\mathrm{ppm})\end{array}$ & 1.05 & 1.17 & 1.19 & 1.13 & 1.05 \\
\hline $\mathrm{Rb}$ & 56 & 376 & 687 & 492 & 346 \\
\hline $\mathrm{Sr}$ & 369 & 63 & 18 & 48 & 59 \\
\hline $\mathrm{Th}$ & 6 & 16 & 8 & 22 & 26 \\
\hline $\mathrm{U}$ & 1 & 8 & 14 & 12 & 8 \\
\hline $\mathrm{Zr}$ & 60 & 70 & 38 & 122 & 113 \\
\hline $\mathrm{La}$ & 21 & 21 & 7 & 32 & 40 \\
\hline $\mathrm{Ce}$ & 42 & 41 & 23 & 70 & 84 \\
\hline $\mathrm{Nd}$ & 13 & 17 & 12 & 31 & 31 \\
\hline
\end{tabular}

${ }^{\text {a }} \mathrm{A} / \mathrm{CNK}=$ molar $\mathrm{Al}_{2} \mathrm{O}_{3} /\left(\mathrm{CaO}+\mathrm{Na}_{2} \mathrm{O}+\mathrm{K}_{2} \mathrm{O}\right)$

re-interpretation has concluded the younger analysis to represent $\mathrm{Pb}$ loss (M. Wingate pers. comm., March 14, 2016), it remained unclear as to whether the $1681 \pm 10$ Ma population should be interpreted as the crystallization age or a maximum for crystallization. Whole-rock geochemistry of the geochronology sample (Table 1) indicates that it has low $\mathrm{Zr}(70 \mathrm{ppm})$ and low $\mathrm{Sr}(63 \mathrm{ppm})$ contents and elevated rare-earth element contents (( $\mathrm{La}, \mathrm{Ce}$ and $\mathrm{Nd})$.

\section{GSWA 183287, 183288, and 187401}

Sample GSWA 183287 is a medium- to coarse-grained, equigranular muscovite-tourmaline granodiorite with 5\% tourmaline and garnet (Figs. 3c, 4c). The presence of partly sericitised plagioclase, recrystallised quartz, and minor myrmekitic textures suggest a thermal overprint. The zircons are typically anhedral, up to $150 \mu \mathrm{m}$ long, ranging from colourless to brown and most grains have idiomorphic zoning (Kirkland et al. 2009). Zircons from this sample yielded a range of dates between 2085 and $1309 \mathrm{Ma}$, interpreted as the ages of xenocrystic zircon (Kirkland et al. 2009) because the granite cross-cuts Neoproterozoic metamorphic fabrics in surrounding metasedimentary rocks (Sheppard et al. 2007). GSWA 183288 is a strongly porphyritic medium-grained, biotite-muscovite-tourmaline monzogranite. It contains about $15 \%$ biotite and $2 \%$ muscovite and tourmaline combined. Plagioclase is partially sericitised, quartz is recrystallised, minor myrmekite is developed, and biotite is partially replaced by chlorite. Zircons from this sample yielded a dominant age component at $1648 \pm 5 \mathrm{Ma}(\mathrm{MSWD}=1.1, n=39 / 41)$ with one older analysis at $1755 \pm 25 \mathrm{Ma}$ (Wingate et al. in press). This monzogranite also cuts Neoproterozoic metamorphic fabrics, so the dominant zircon population must represent the age of the main source component. In both instances, zircon geochronology was unable to constrain the emplacement age.

Sample GSWA 187401 is a fine- to medium-grained, equigranular tourmaline-muscovite monzogranite that was sampled by GSWA for zircon geochronology, but was not analysed. It contains tourmaline nodules with leucocratic halos (Fig. 4d). The monzogranite contains muscovite, and roughly $5 \%$ ferromagnesian minerals (biotite, tourmaline, epidote, and titanite). Recrystallised quartz, minor sericitisation, and myrmekite are indicative of minor post-magmatic deformation (Fig. 3d). 

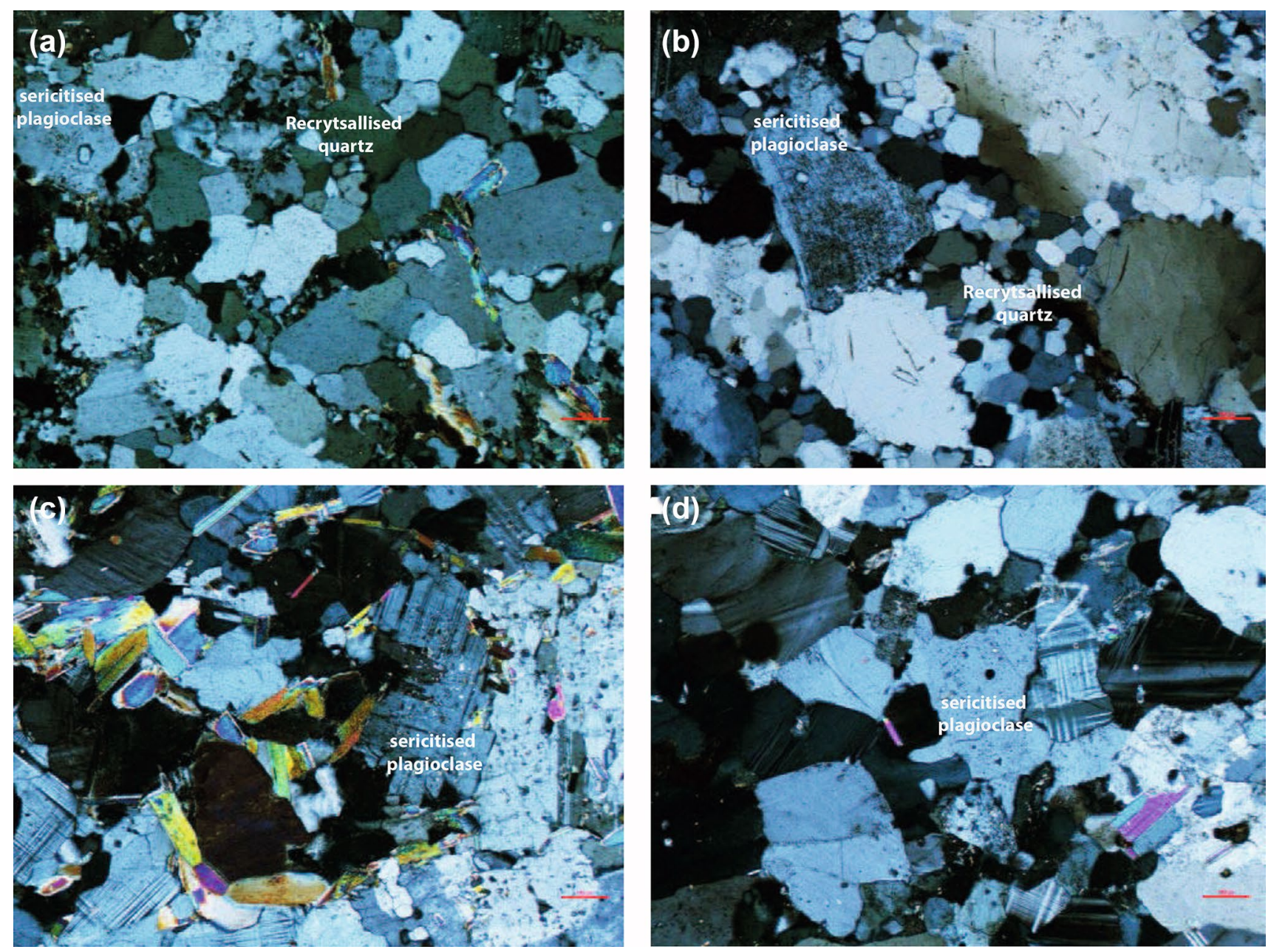

Fig. 3 Representative photomicrograph images (cross polarised light) highlighting a weak post-magmatic overprint observed in the leucogranites samples a 139466: medium-grained equigranular biotite-muscovite granodiorite showing minor sericitisation and quartz recrystallization; b 169092: massive, medium-grained biotite-muscovite monzogranite, showing minor sericite, quartz recrystallisation

and undulose extinction in the quartz; c 183287: medium- to coarsegrained, equigranular muscovite-tourmaline granodiorite with partly sericitised plagioclase and recrystallised quartz; d 187401: fine to medium-grained equigranular tourmaline-muscovite monzogranite showing recrystallised quartz and minor sericitisation

The three samples (183287, 183288 and 187401) have relatively low whole-rock $\mathrm{Zr}$ and $\mathrm{Sr}$ concentrations (Table 1). Of the three samples, 183287 shows significantly lower abundances of $\mathrm{Th}, \mathrm{La}, \mathrm{Ce}$, and $\mathrm{Nd}$.

\section{Analytical methods}

Monazite from three leucocratic granite samples (GSWA 139466, 169092 and 183287) were separated using standard mineral separation methods (Wingate and Lu 2016), and cast in 25-mm-diameter epoxy mounts which were then polished to expose the interiors of the crystals. No monazite grains were found in sample GSWA 183288. For sample GSWA 187401, polished thin sections were imaged using a scanning electron microscope (SEM) in

back-scattered electron (BSE) mode fitted with an energy dispersive X-ray spectrometer (EDS) to identify suitable monazite grains for in situ SHRIMP geochronology. Monazite grains $>10 \mu \mathrm{m}$ across were drilled out in 3-mmdiameter plugs and cast in a single 25-mm epoxy mount. Monazite reference materials FRENCH, Z2908, Z2234, and PD95 were in a separate mount that was cleaned and Au-coated with the sample mounts prior to analysis. Monazite reference OX1 was located on the same mount as the unknowns (183287).

$\mathrm{U}-\mathrm{Th}-\mathrm{Pb}$ analyses of monazite were conducted using a SHRIMP II ion microprobe in the John de Laeter Centre at Curtin University, Perth. Optical and BSE images were used to guide placement of the primary ion beam during SHRIMP analysis. The SHRIMP instrument setup and operating protocols followed the established 

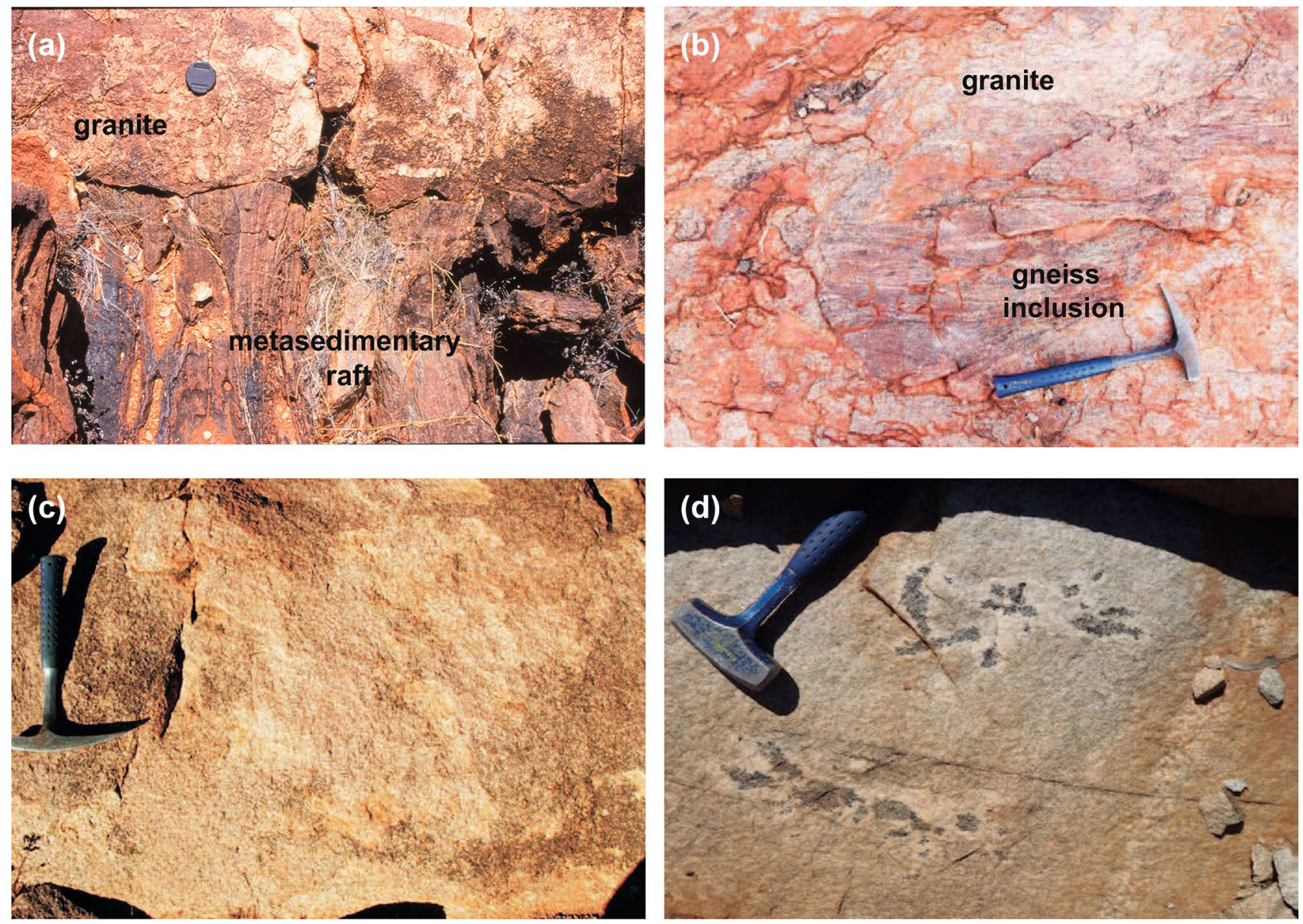

Fig. 4 Field photos $(\sim 7 \mathrm{~cm}$ camera cover in (a) and $\sim 30 \mathrm{~cm}$ long hammer in (b-d) for scale: a an undeformed coarse-grained granite dyke of the Erong Granite cutting the deformation fabrics in metasedimentary gneiss; b gneiss inclusion in the Durlacher Granite about $1 \mathrm{~km}$ from the Red Rock Bore granite locality; c sample 183287: a

procedure for small spot analysis of monazite (Fletcher et al. 2010). A total of six sessions were conducted to obtain the $\mathrm{U}-\mathrm{Th}-\mathrm{Pb}$ data presented here. During all sessions, an $\mathrm{O}^{2-}$ primary beam focused through a $30-\mu \mathrm{m}$ Kohler aperture to produce a spot size $\sim 10 \mu \mathrm{m}$, with a beam intensity of $0.2-0.4 \mathrm{nA}$. The secondary ion system was focused through a $100-\mu \mathrm{m}$ collector slit onto an electron multiplier to produce mass peaks with flat tops and a mass resolution $(M / \Delta M$ at $1 \%$ peak height $)$ of $>5000$ in all sessions. Post-collector retardation lens was activated to reduce stray ions. Squid-2.50.11.02.03 software (Ludwig 2009) was used for initial data reduction, including correction for common $\mathrm{Pb}$. Corrections for matrix effects in ${ }^{206} \mathrm{~Pb} /{ }^{238} \mathrm{U}$ and ${ }^{208} \mathrm{~Pb} /{ }^{232} \mathrm{Th}$, and for instrumental mass fractionation in ${ }^{207} \mathrm{~Pb} /{ }^{206} \mathrm{~Pb}$, were applied to monazite data (Fletcher et al. 2010). To adjust for analytical medium- to coarse-grained, equigranular muscovite-tourmaline granodiorite of the Thirty-Three Supersuite; d sample 187401: coarsegrained equigranular tourmaline-muscovite monzogranite of the Thirty-Three Supersuite with distinct tourmaline nodules

bias the respective 1 sigma calibration uncertainty was applied in quadrature to ${ }^{238} \mathrm{U} /{ }^{206} \mathrm{~Pb}$ and ${ }^{232} \mathrm{Th} /{ }^{208} \mathrm{~Pb}$ individual analyses (samples 187401 and 183287) prior to the calculation of the weighted mean. Weighted mean dates are reported with $95 \%$ confidence limits, whereas individual analyses are presented with $1 \sigma$ uncertainties. Because our samples span almost a billion years, from the Paleoproterozoic to Neoproterozoic, the choice of isotopic system $\left({ }^{207} \mathrm{~Pb} /{ }^{206} \mathrm{~Pb},{ }^{238} \mathrm{U} /{ }^{206} \mathrm{~Pb}\right.$, and $\left.{ }^{232} \mathrm{Th} /{ }^{208} \mathrm{~Pb}\right)$ is sample dependent (e.g., Kirkland and Wingate 2012). For Paleoproterozoic and older samples the ${ }^{207} \mathrm{~Pb} /{ }^{206} \mathrm{~Pb}$ analysis is typically the most precise and preferred for weighted mean calculation. However, from late Mesoproterozoic ${ }^{238} \mathrm{U} /{ }^{206} \mathrm{~Pb}$ or ${ }^{232} \mathrm{Th} /{ }^{208} \mathrm{~Pb}$ ratios provide the most reliable age estimates. The precisions of ${ }^{238} \mathrm{U}$ and ${ }^{232} \mathrm{Th}$ abundances measured by SHRIMP are typically $5-10 \%$. 


\section{Monazite geochronology results}

SHRIMP U-Th- $\mathrm{Pb}$ monazite data are presented in Supplementary Table 3 and are summarised in Table 2, which also includes $\mathrm{U}-\mathrm{Pb}$ zircon data from previous work for comparison.

\section{Sample 139466: biotite-muscovite granodiorite}

Monazite crystals from this sample are yellow, transparent, and unzoned. They are subhedral to predominantly anhedral and range in size from 50 to $>100 \mu \mathrm{m}$. Monazite occurs primarily as inclusions in quartz, but is also hosted in plagioclase. Thirteen analyses were carried out on eight monazite grains (Supplementary Table 3). Excluded from age calculations are a single concordant analysis that indicates high common $\mathrm{Pb}\left(f_{206}>1 \%\right)$ and another that is $>10 \%$ discordant. The remaining 11 analyses are $<5 \%$ discordant and indicate low common $\mathrm{Pb}$. Ten of the 11 analyses indicate well-grouped, measured $\mathrm{U}$ and $\mathrm{Th}$ concentrations that vary from 350 to $500 \mathrm{ppm}$ and 21,400 to $37,500 \mathrm{ppm}$, respectively, with $\mathrm{Th} / \mathrm{U}$ ratios from 54 to 88 . They yielded ${ }^{207} \mathrm{~Pb} /{ }^{206} \mathrm{~Pb}$ dates between 1868 and $1787 \mathrm{Ma}$, with a weighted mean of $1830 \pm 19 \mathrm{Ma}(\mathrm{MSWD}=2.8)$. Despite the large MSWD, rejection of additional analyses is not warranted given the uniformity of these monazites in morphology and U-Th composition. Therefore, $1830 \pm 19 \mathrm{Ma}$ (Fig. 5a) is considered the best estimate of the timing of monazite growth during magma crystallisation. An old outlier yielded a ${ }^{207} \mathrm{~Pb} /{ }^{206} \mathrm{~Pb}$ date of $1933 \pm 7 \mathrm{Ma}(1 \sigma)$, and is interpreted to be a xenocryst.

\section{Sample 169092: biotite-muscovite monzogranite}

Monazite is widespread in this rock and occurs as inclusion in quartz, plagioclase, undeformed muscovite, and in biotite. Monazites crystals are $>100 \mu \mathrm{m}$ in size, yellow and transparent, and mainly subhedral and unzoned. Thorium concentrations range from 42,700 to $73,800 \mathrm{ppm}$, whereas U concentrations are bimodal: 1000-1900 ppm (four analyses) and 3500-7900 ppm (13 analyses). The $\mathrm{Th} / \mathrm{U}$ ratios range from 8 to 70 . Twenty-five analyses were obtained from 14 monazite grains; seven analyses that show $>5 \%$ discordance are disregarded. A single analysis yielding a date of $1663 \pm 2 \mathrm{Ma}(1 \sigma)$ is considered an outlier due to its significantly higher $\mathrm{U}(17,600 \mathrm{ppm})$ and lower Th $(34,700 \mathrm{ppm})$ and resultant much lower Th/U (2 vs. 8-70) compared with the range seen in the main population (Supplementary Table 3). The remaining 17 analyses of 14 monazite grains yielded a weighted mean ${ }^{207} \mathrm{~Pb} /{ }^{206} \mathrm{~Pb}$ date of $1682 \pm 3 \mathrm{Ma}$ (MSWD =0.99) (Fig. 5b), interpreted as the age of igneous crystallisation, consistent with the main age component of the initial zircon age.

\section{Sample 187401: tourmaline-muscovite monzogranite}

Monazite crystals in this sample show two different morphologies: (i) subhedral crystals $30-60 \mu \mathrm{m}$ in size, and (ii) larger $(>100 \mu \mathrm{m})$ anhedral crystals. The anhedral types are typically associated with secondary apatite and show retrogression coronas (e.g., Finger et al. 1998). However, the effect of post-magmatic alteration is not evident from the concordant age data, which ranges from 1058 to $970 \mathrm{Ma}\left({ }^{238} \mathrm{U} /{ }^{206} \mathrm{~Pb}\right)$ across the monazite grains. The

Table 2 Summary of field data, U-Pb zircon and $\mathrm{U}-\mathrm{Th}-\mathrm{Pb}$ monazite geochronology for leucocratic granite samples

\begin{tabular}{|c|c|c|c|c|c|c|c|}
\hline Sample ID & Easting & Northing & Rock type & Stratigraphic unit & $\begin{array}{l}\text { Zircon }{ }^{207} \mathrm{~Pb}^{*} / 206 \mathrm{~Pb} \\
\text { age (Ma) }\end{array}$ & Monazite age (Ma) & $\begin{array}{l}\text { Isotopic system used } \\
\text { for monazite }\end{array}$ \\
\hline GSWA 139466 & 465700 & 7174600 & $\begin{array}{l}\text { Biotite-muscovite } \\
\text { granodiorite }\end{array}$ & $\begin{array}{l}\text { Moorarie Super- } \\
\text { suite }\end{array}$ & $2621 \pm 9$ & $1830 \pm 19$ & ${ }^{207} \mathrm{~Pb}^{*} / 206 \mathrm{~Pb}^{*}$ \\
\hline GSWA 169092 & 361420 & 7409000 & $\begin{array}{l}\text { Biotite-muscovite } \\
\text { monzogranite }\end{array}$ & $\begin{array}{l}\text { Durlacher Super- } \\
\text { suite }\end{array}$ & $\begin{array}{c}1681 \pm 10 \\
1619 \pm 15\end{array}$ & $1682 \pm 3$ & ${ }^{207} \mathrm{~Pb}^{*} / 206 \mathrm{~Pb}^{*}$ \\
\hline GSWA 187401 & 418385 & 7286232 & $\begin{array}{l}\text { Tourmaline-mus- } \\
\text { covite monzo- } \\
\text { granite }\end{array}$ & $\begin{array}{l}\text { Thirty-Three } \\
\text { Supersuite }\end{array}$ & - & $1006 \pm 14$ & ${ }^{238} \mathrm{U} /{ }^{206} \mathrm{~Pb}^{*}$ \\
\hline GSWA 183287 & 422561 & 7287407 & $\begin{array}{l}\text { Muscovite-tourma- } \\
\text { line granodiorite }\end{array}$ & $\begin{array}{c}\text { Thirty-Three } \\
\text { Supersuite }\end{array}$ & 2085-1309 & $899 \pm 10$ & ${ }^{232} \mathrm{Th} /{ }^{208} \mathrm{~Pb}^{*}$ \\
\hline GSWA 183288 & 423293 & 7288459 & $\begin{array}{l}\text { Biotite-muscovite- } \\
\text { tourmaline } \\
\text { monzogranite }\end{array}$ & $\begin{array}{c}\text { Thirty-Three } \\
\text { Supersuite }\end{array}$ & $1648 \pm 5$ & - & \\
\hline
\end{tabular}

$\mathrm{Pb}^{*}$ indicates radiogenic $\mathrm{Pb}$ (i.e., corrected for common $\mathrm{Pb}$ )

The choice of isotopic system used to calculate the weighted mean for monazite data is discussed in the text

Sample locations quoted in coordinate system MGA 1994 GDA Zone 50

- Not analysed. Monazite was not found in sample 183288. Sample 187401 was not submitted for routine zircon geochronology due to leucocratic nature 

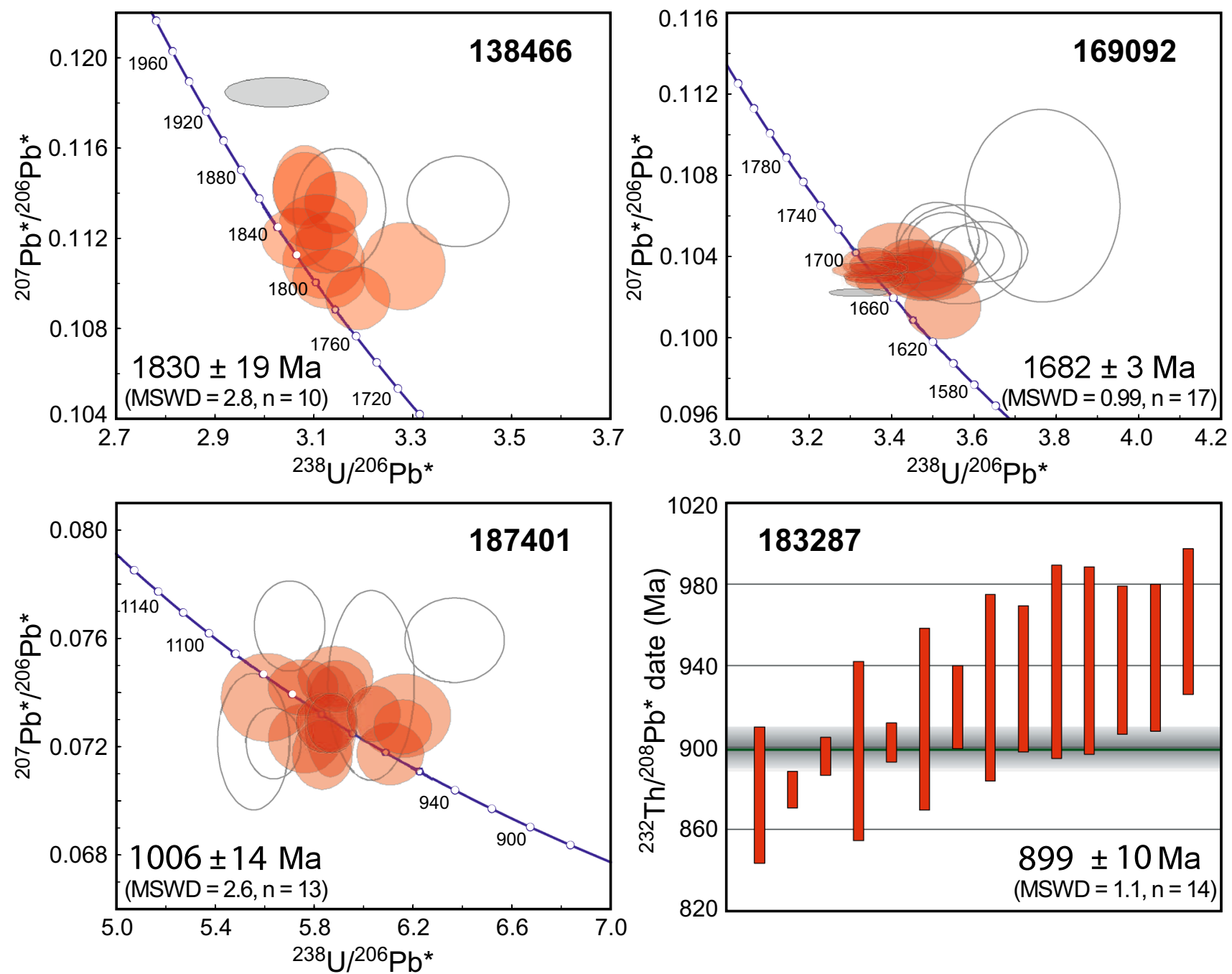

Fig. 5 SHRIMP U-Th-Pb analytical results for monazite from leucocratic granites in the Gascoyne Province. Ellipses in the concordia diagrams (d-f) correspond to analyses with $1 \sigma$ uncertainties; red ellipses represent the main group of analyses; grey ellipses denote analyses with high common $\mathrm{Pb}$, and open ellipse indicate discordance
$>5 \%$. Weighted mean dates are ${ }^{207} \mathrm{~Pb} /{ }^{206} \mathrm{~Pb}(\mathbf{a}-\mathbf{b})$ and ${ }^{206} \mathrm{~Pb} /{ }^{238} \mathrm{U}(\mathbf{c})$. a Erong Granite sample GSWA 139466; b leucocratic granite sample GSWA 169092; c Thirty-Three Supersuite sample GSWA 187401; d Thirty-Three Supersuite sample GSWA 183287 weighted mean ${ }^{232} \mathrm{Th} /{ }^{208} \mathrm{~Pb}$ plot. Mean ages are quoted with $95 \%$ confidence intervals

group of analyses was also used to calculate a weighted mean ${ }^{207} \mathrm{~Pb} /{ }^{206} \mathrm{~Pb}$ date of $1018 \pm 16(\mathrm{MSWD}=1.5)$. Excluding an analysis that yielded an imprecise ${ }^{232} \mathrm{Th} /{ }^{208} \mathrm{~Pb}$ date, 18 analyses give a weighted mean ${ }^{232} \mathrm{Th} /{ }^{208} \mathrm{~Pb}$ age of $1047 \pm 20($ MSWD $=1.5)$. The weighted mean dates derived from the ${ }^{207} \mathrm{~Pb} /{ }^{206} \mathrm{~Pb}$ and ${ }^{238} \mathrm{U} /{ }^{206} \mathrm{~Pb}$ decay systems agree within uncertainty and because this sample falls within the Mesoproterozoic-Neoproterozoic boundary either the ${ }^{207} \mathrm{~Pb} /{ }^{206} \mathrm{~Pb}$ or ${ }^{238} \mathrm{U} /{ }^{206} \mathrm{~Pb}$ could be used to represent the age of crystallisation. However, the individual ${ }^{238} \mathrm{U} /{ }^{206} \mathrm{~Pb}$ analyses are more precise with uncertainties two to three times lower than for ${ }^{207} \mathrm{~Pb} /{ }^{206} \mathrm{~Pb}$; therefore, the ${ }^{238} \mathrm{U} /{ }^{206} \mathrm{~Pb}$ date of $1006 \pm 14 \mathrm{Ma}$ is taken as the most reliable estimate of the crystallisation age. 

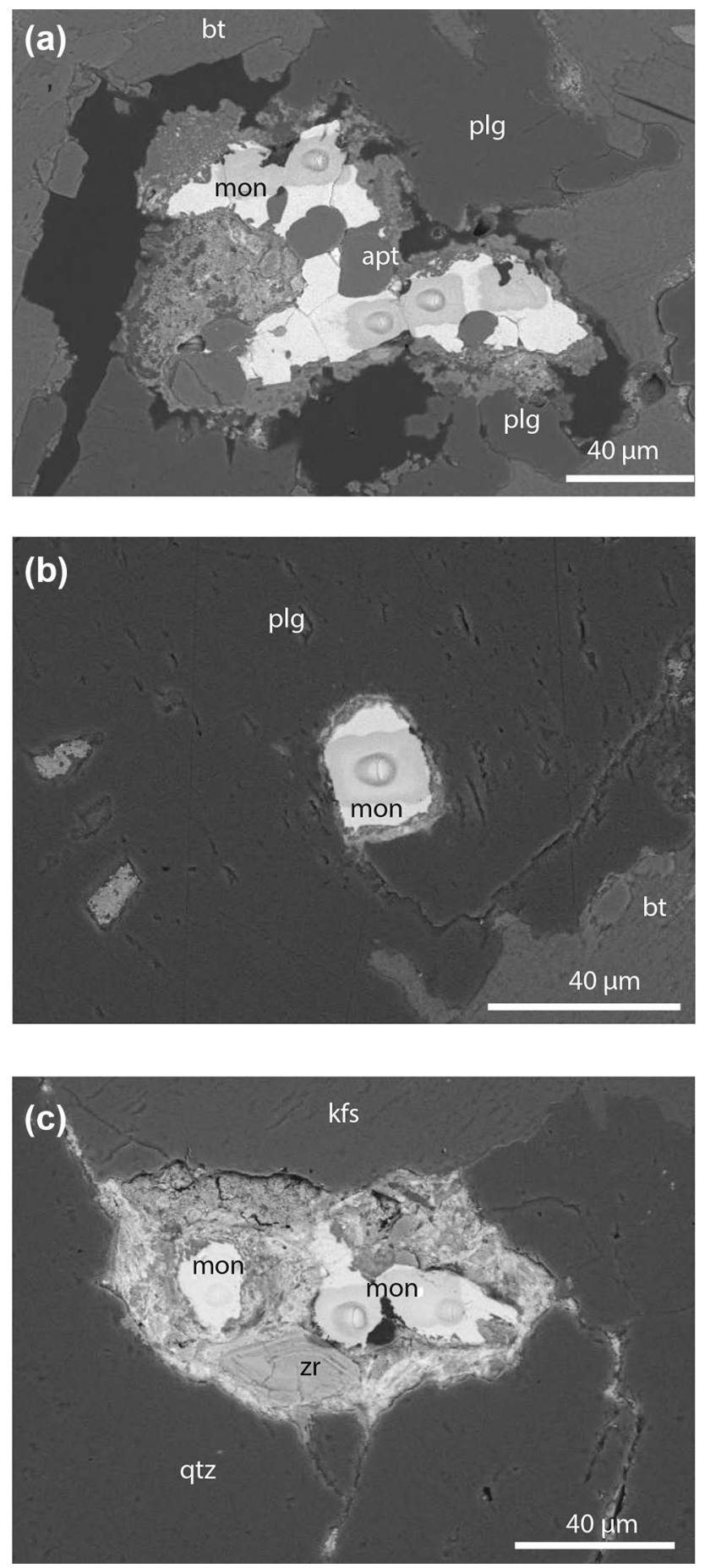

Fig. 6 Back-scattered electron (BSE) images of representative in situ monazite from sample GSWA $187401(\mathbf{a}-\mathbf{c})$. SHRIMP pits shown by the circles and the haloes around the SHRIMP spots show the effect of the raster. a Monazite growth associated with secondary apatite; $\mathbf{b}$ subhedral monazite within plagioclase feldspar; c multiple anhedral monazites in between quartz and $\mathrm{K}$-feldspar ( $\mathrm{Fe}$ alteration around the monazite). (bt biotite, plg plagioclase feldspar, mon monazite, apt apatite, $k f s \mathrm{~K}$-feldspar, qtz quartz, $z r$ zircon). Dark circles are SHRIMP pits with a raster halo

\section{Sample 183287: biotite-muscovite-tourmaline monzogranite}

Monazite crystals from this sample are subhedral to anhedral, and yellow and transparent, with an average size of $60 \mu \mathrm{m}$ (Fig. 7). The crystals occur as inclusions in quartz and plagioclase. Compared with those from sample 187401, monazites from this sample contain significantly lower $\mathrm{U}$ and $\mathrm{Th}$ concentrations ranging from 250 to $750 \mathrm{ppm}$ and from 14,800 to $40,500 \mathrm{ppm}$, respectively, but with more uniform and elevated $\mathrm{Th} / \mathrm{U}$ ratios (52-61, with an average of 54). Sixteen analyses were obtained from seven monazite grains (Supplementary Table 3). For this sample, dates determined from ${ }^{207} \mathrm{~Pb} /{ }^{206} \mathrm{~Pb}$ or ${ }^{238} \mathrm{U} /{ }^{206} \mathrm{~Pb}$ ratios are significantly more dispersed and discordant than those based on ${ }^{232} \mathrm{Th} /{ }^{208} \mathrm{~Pb}$ ratios, and several analyses indicate high common ${ }^{206} \mathrm{~Pb}$, whereas common ${ }^{208} \mathrm{~Pb}\left(f_{208}\right.$ in Supplementary Table 3) is, with one exception, $<1 \%$. Excluding the single analysis with high common ${ }^{208} \mathrm{~Pb}$ $(>1 \%)$, and one old outlier, 14 analyses of six monazites yielded a weighted mean ${ }^{232} \mathrm{Th} /{ }^{208} \mathrm{~Pb}$ date of $899 \pm 10 \mathrm{Ma}$ $(\mathrm{MSWD}=1.1)($ Supplementary Table 3$)$. Weighted mean dates calculated using ${ }^{207} \mathrm{~Pb} /{ }^{206} \mathrm{~Pb}$ and ${ }^{238} \mathrm{U} /{ }^{206} \mathrm{~Pb}$ ratios, applying the discordance and common $\mathrm{Pb}$ criteria as above (cut-off value at $1 \%$ for $f_{206}$ and $\pm 5 \%$ for discordance), are $907 \pm 24(n=6$, MSWD $=1.3)$ and $917 \pm 25(n=6$, MSWD $=2.0)$, respectively. The results show that the ${ }^{238} \mathrm{U} /{ }^{206} \mathrm{~Pb},{ }^{207} \mathrm{~Pb} /{ }^{206} \mathrm{~Pb}$ and ${ }^{232} \mathrm{Th} /{ }^{208} \mathrm{~Pb}$ weighted mean ages are indistinguishable within uncertainty; however, the overall weighted mean is most precise for the ${ }^{232} \mathrm{Th} /{ }^{208} \mathrm{~Pb}$ system; therefore, for this Neoproterozoic sample, we consider the ${ }^{232} \mathrm{Th} /{ }^{208} \mathrm{~Pb}$ age of $899 \pm 10 \mathrm{Ma}$ to be the best estimate of the age of igneous crystallisation (Fig. 5d).

\section{Discussion}

Igneous crystallisation ages for some leucocratic granites are difficult to determine using $\mathrm{U}-\mathrm{Pb}$ zircon geochronology because these low-temperature crustal melts commonly contain a significant proportion of inherited zircon (e.g., Crowley et al. 2008; Harrison et al. 1999; Scott et al. 2011). The samples in this study contain $\mathrm{Zr}$ contents $<150 \mathrm{ppm}$, which according to Miller et al. (2003) is a criterion for potential zircon inheritance in a melt. Due to the historic issue of xenocrystic zircons in the leucocratic granites in the Gascoyne Province, an alternative was required to determine the crystallisation age of these granites. Monazite is a common accessory mineral in a wide variety of granitic rocks, and, in particular, is commonly found as primary monazite in peraluminous leucogranites. Magmatic 

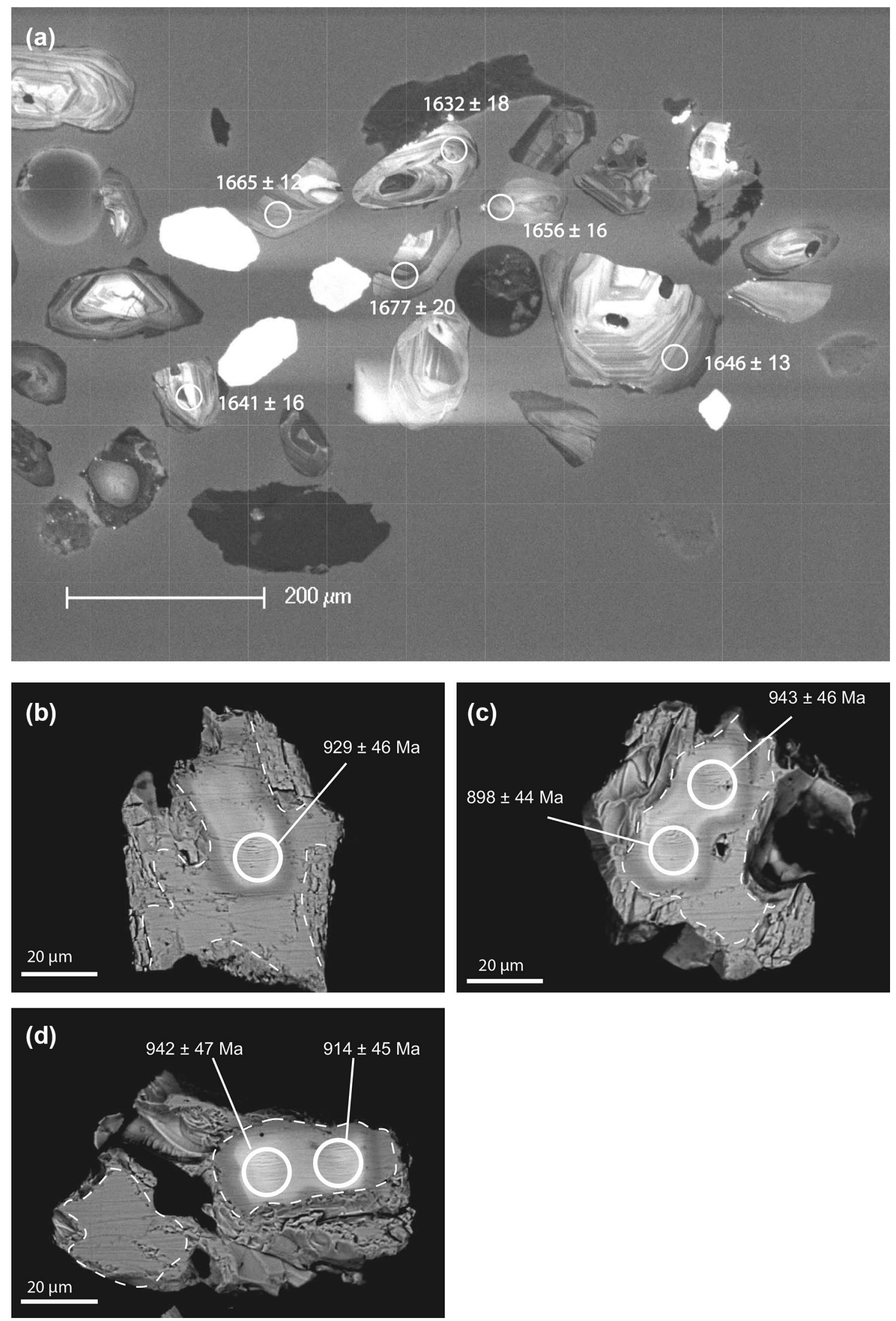
4Fig. 7 Cathodoluminescence image of representative zircon grains from sample 183287 showing the original xenocrystic zircon ages (Kirkland et al. 2009) (a). Back-scattered electron (BSE) images of representative separated monazite grains from 183287 plus SHRIMP pits and corresponding ages from sample GSWA 183287 (b-d) subhedral to anhedral monazite grains typically around $60 \mu \mathrm{m}$ in size. Zoning indicated by dashed outline. SHRIMP pits are shown by the circles and the haloes around the SHRIMP spots show the effect of the raster

monazite is distinguished from metamorphic monazite by observing the textural context of the crystals and noticing any effects of post magmatic deformation experienced by the rock. Here we show how obtaining reliable crystallization ages is important to determine the duration and extent of major granitic events and associated orogenic activity.

\section{Assessment of magmatic monazite}

Igneous monazite may become unstable during low- to medium-grade regional metamorphism (Townsend et al. 2001) resulting in secondary apatite-allanite coronas (Finger et al. 1998). The in situ monazite crystals in the tourmaline-muscovite monzogranite sample (GSWA 18740) are accompanied by secondary apatite and display some reaction coronas (Fig. 6). Although some monazite crystals in sample 187401 show secondary alteration rims, both monazite inclusions in plagioclase and interstitial monazite yielded similar ages. Although magmatic monazites typically show zoning (Bea 1996; Broska et al. 2000; Crowley et al. 2008; Montel 1993; Townsend et al. 2001), we found that only monazite in the muscovite-tourmaline granodiorite (GSWA 183287) shows zoning (Fig. 7); despite this, small-spot analysis enabled the primary monazite to be targeted and the results show consistent dates across the grains (Supplementary Table 3).

In sample 187401 the monazite crystals hosted in quartz and plagioclase suggest that monazite crystallised with the melt in contrast to inclusions in biotite that may contain inherited monazite (Rapp and Watson 1986). For the grain-mounted samples (139466, 169092 and 183287), monazite is found as inclusions in quartz and plagioclase and, more rarely, in biotite and muscovite or as an interstitial mineral. The results in Copeland et al. (1988) suggested that that monazite inheritance is common in Tertiary S-types granites. Although the original location of the analysed monazite crystals is not known, our data contain only one analysis of inherited monazite (sample 139466) across four granite samples. This confirms the suggestion by Parrish (1990) that monazite inheritance is less common than zircon in granites and, in particular, Precambrian granites.

Typically magmatic monazite shows a consistent pattern of elevated Th and moderate U concentrations. In Fig. 8, the $\mathrm{Th}$ and $\mathrm{U}$ concentrations of monazite analysed in this study are compared with monazite from other granites. The plot shows that our monazites are consistent with the Th and $U$ signature of igneous monazites presented in other studies. Lower $\mathrm{U}$ and $\mathrm{Th}$ concentrations distinguish magmatic monazite from hydrothermal monazite and monazite grown during low-temperature metamorphism or mineralisation from the southern Pilbara margin (Rasmussen et al. 2005) and the Abra deposit in the Capricorn Orogen ( $\mathrm{Zi}$ et al. 2015) (Fig. 8). However, monazite related to mediumgrade metamorphism may yield similar Th and U concentrations to magmatic monazite (e.g., U ranges from 1100 to $6700 \mathrm{ppm}$ and Th from 1200 to $104,800 \mathrm{ppm}$, Sheppard et al. 2007). Although the rocks in this study show signs of minor recrystallisation related to low-grade metamorphic overprints the absence of multiple age populations in individual samples suggest that the post-magmatic effects are minimal. Additionally, the two samples that display minor alteration of monazite (183287 and 187401), these zones could be avoided due to careful placement of the analytical spot. The leucocratic granites lack any evidence of a medium-grade metamorphic overprint (Fig. 3) and demonstrably post-date regional metamorphic fabrics. Therefore, considering the textural context of the monazites and the observed minimal post-magmatic alteration we conclude that the monazites analysed are magmatic in origin.

\section{Implications of the monazite geochronology}

Correctly dating the timing and duration of magmatism is essential both for reconstructing reliable tectonic histories in complex intracratonic orogenic belts and for addressing the thermal history of orogens. Below we examine the wider implications of our new geochronology results.

\section{The life-span of an orogeny}

Many Precambrian orogenic belts dominated by low- to medium-grade metamorphic rocks lack direct metamorphic ages (and when biostratigraphy is not available); the ages of granitic supersuites have been used as a proxy for the duration of orogenic events (e.g., the 1680-1620 Ma Durlacher Supersuite, Sheppard et al. 2005). The biotitemuscovite monzogranite (GSWA 169092) in the far north of the province yielded zircon results that were inconclusive and allowed for two possible interpretations of the igneous crystallisation age. However, our monazite geochronology provides an unambiguous igneous crystallisation age of $1682 \pm 3 \mathrm{Ma}$ for sample 169092, indicating that it was emplaced during the main stage of magmatism (1688-1659 Ma). There is a lack of evidence for granites younger than c. $1659 \mathrm{Ma}$ in the Durlacher Supersuite in the northern Gascoyne Province suggesting that magma emplacement occurred over a shorter interval (Fig. 9) than 


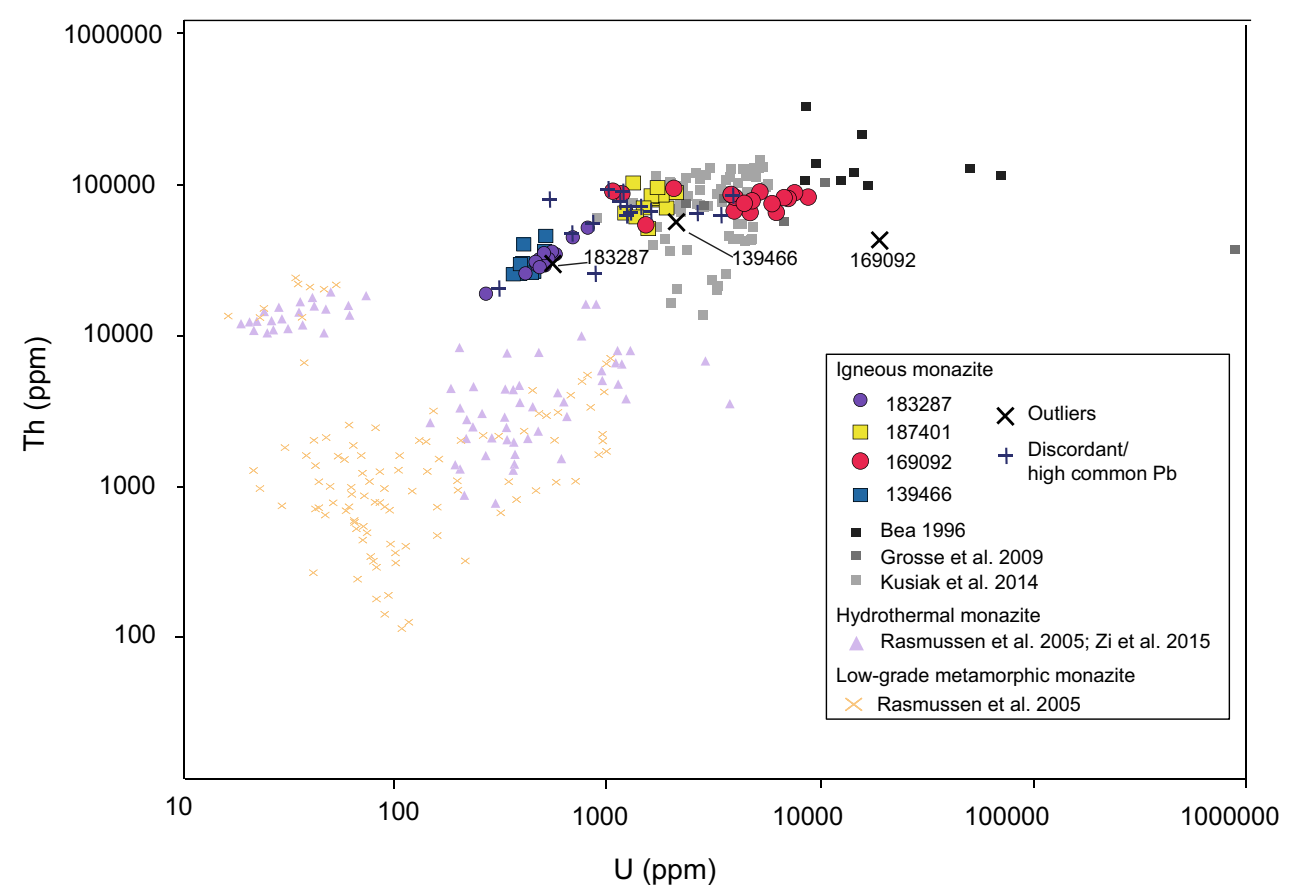

Fig. 8 Diagram of Th versus U concentrations in monazite from leucocratic granites analysed in this study, and published data (Bea 1996; Grosse et al. 2009; Kusiak et al. 2014), relative to the field for hydrothermal monazites ( $\mathrm{Zi}$ et al. 2015), and low grade metamor-

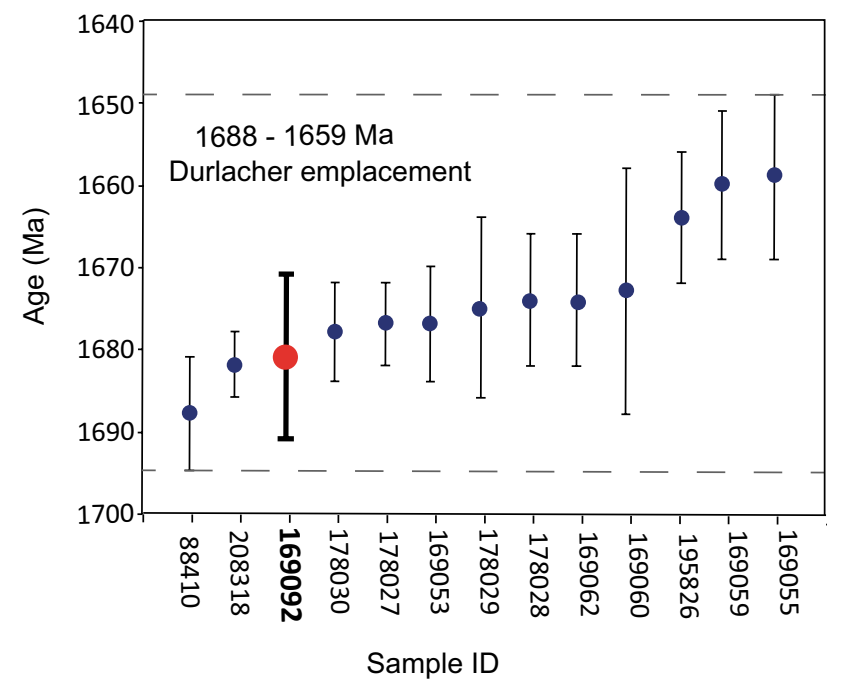

Fig. 9 Zircon dates from Durlacher Supersuite granites in the northern Gascoyne Province (GSWA 2016b). The data indicate that magmatism in the northern Gascoyne spanned c. 30 million years and ceased by c. 1659 Ma. Error bars indicate 95\% confidence intervals

previously thought by Sheppard et al. (2005). In turn, new data imply a higher flux of felsic magma generation during intracontinental reworking and that the reworking was of shorter duration than previously supposed. Sample GSWA 169092 and the c. 1620 Ma Discretion Granite was used phism and mineralisation (Rasmussen et al. 2005) and medium grade metamorphism (Sheppard et al. 2007) from study areas in the Capricorn Orogen. The plot shows a clear distinction between igneous monazite and hydrothermal and low-grade metamorphism

to provide a younger limit to the Durlacher Supersuite and tectonothermal activity during the Mangaroon Orogeny (Sheppard et al. 2005). However, the Discretion Granite (Fig. 1c) appears to be an episode of felsic magmatism isolated in space and time, and may either belong to a discrete tectonothermal event or be related to a flare-up of intracratonic reworking far to the southeast.

\section{A slow-burning supersuite}

The Thirty-Three Supersuite (995-955 Ma) comprises $\sim 420 \mathrm{~km}^{2}$ of leucocratic granite plutons and pegmatites restricted to the central part of the Gascoyne Province. Volumetrically, the supersuite is by far the smallest of the four supersuites in the province. Despite being emplaced in a narrow structural corridor, the timing of the Thirty-Three Supersuite has proven difficult to constrain. The initial zircon geochronology and our new monazite results are discussed below.

Zircon geochronology Initial U-Pb zircon geochronology for one pluton of the Thirty-Three Supersuite yielded a date of $1652 \pm 5 \mathrm{Ma}$, interpreted as the crystallisation age (sample KC063, a biotite-muscovite-tourmaline monzogranite; Culver 2001). At that time this age appeared to be consistent with the field relationships for two reasons: (1) tectonic fabrics in surrounding metasedimentary rocks cut 
by the plutons were considered to be Paleoproterozoic, and (2) the leucocratic granites do not intrude the unconformably overlying 1620-1450 Ma metasediments (Fig. 2c). However, later monazite geochronology established that the metamorphic assemblages are actually related to the 1030950 Ma Edmundian Orogeny and that a large rare-earthelement-bearing pegmatite considered to be associated with the leucocratic granites has an igneous crystallisation age of $954 \pm 12$ Ma (Sample 117154, Sheppard et al. 2007). Further $\mathrm{U}-\mathrm{Pb}$ zircon geochronology of the leucocratic granites yielded zircon dates that were interpreted as representing the ages of xenocrystic zircon. A biotite-muscovite-tourmaline monzogranite (183287) yielded zircon populations between 2085 and $1309 \mathrm{Ma}$ (Kirkland et al. 2009), and secondly, a muscovite-tourmaline monzogranite (183288) yielded a single age population $1648 \pm 5 \mathrm{Ma}$ (Wingate et al. in press).

Pegmatites Additional zircon geochronology on pegmatites (samples GSWA 185946, 185945 and 190667) in the area established igneous crystallisation ages, respectively, of $1030 \pm 6,1000 \pm 8$, and $939 \pm 5 \mathrm{Ma}$ (Wingate et al. 2011, 2010a, b) better aligned with the field relationships and existing phosphate geochronology. Furthermore, monazite from a tourmaline-rich schist which is part of a metasomatic halo around a tourmaline-bearing pegmatite dyke yielded a date of $958 \pm 16$ Ma (Sample GSWA 88475 Fig. 2c; Korhonen et al. 2015).

Monazite geochronology Our monazite data from two leucocratic samples, of the Thirty-Three Supersuite, yielded Neoproterozoic ages consistent with the metamorphic fabrics in the adjacent rocks. Sample 187401, a tourmalinemuscovite monzogranite, yielded an age of $1006 \pm 14 \mathrm{Ma}$ representing the initial stages of magmatism. Furthermore, our results highlight that magmatism continued until c. 899 Ma (sample 183287: biotite-muscovite-tourmaline monzogranite).

The combined monazite and zircon data suggest that magmatism of the Thirty-Three Supersuite spanned about 130 million years (c. 1030-899 Ma) and that leucocratic magmatism outlasted the regional metamorphism in the same structural corridor by c. 100 million years (Fig. 10). Furthermore, given the small area (and likely small volume) of the supersuite, the geochronology implies exceptionally low magma production rates. The monazite and zircon geochronology confirm that the Thirty-Three Supersuite is much younger than c. 1620-1465 Ma metasedimentary rocks of the Edmund Group, despite the absence of pegmatite and leucocratic granite in the Edmund Group in the Ti Tree Shear Zone immediately to the north. Therefore, reworking and magmatism must have been funnelled into a narrow structural corridor south of the shear zone from c. $1030 \mathrm{Ma}$ onwards. This work further highlights

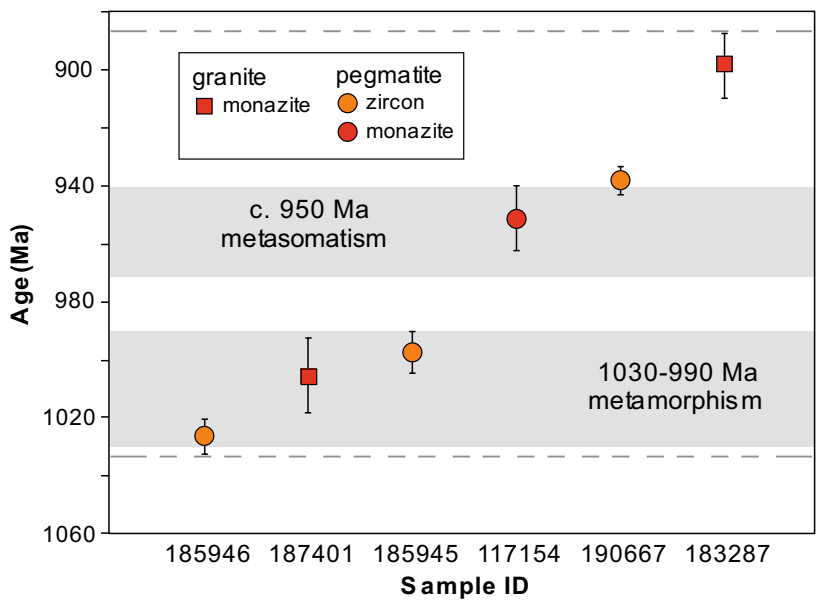

Fig. 10 Monazite and zircon ages for leucocratic granites and pegmatites of the Thirty-Three Supersuite. Two stages of granite and pegmatite are suggested by the combined monazite and zircon geochronology. The first stage corresponds with metamorphism and deformation during the Edmundian Orogeny, whereas the younger pulse may be associated with periodic reactivation of the Ti Tree Shear Zone. Error bars indicate 95\% confidence intervals

the problem of attempting to correlate events across major structures within a complex orogen.

\section{An isolated granite}

Sample GSWA 139466 was taken from a biotite-muscovite granodiorite pluton that intruded a crustal-scale shear zone (the Errabiddy Shear Zone). The existing geochronological constraints allowed the pluton to have been emplaced at any time over a c. 1000 million-year interval. Our U-Th-Pb monazite geochronology yielded a date of $1830 \pm 19 \mathrm{Ma}$, interpreted as the age of igneous crystallisation and is consistent with field relationships that show the Erong Granite cutting deformation fabrics formed during the 2005-1950 Ma Glenburgh Orogeny. The new monazite data indicate that the pluton is part of the voluminous Moorarie Supersuite associated with reworking during the Paleoproterozoic Capricorn Orogeny. This study shows that even for an area shaped by multiple episodes of reworking and reactivation monazite is a powerful geochronometer for constructing a more reliable tectonic and magmatic history of a major shear zone.

\section{Conclusions}

Our study has highlighted the benefits of using $\mathrm{U}-\mathrm{Th}-\mathrm{Pb}$ monazite geochronology for dating peraluminous leucocratic, low-temperature granites. This study has demonstrated that $\mathrm{U}-\mathrm{Th}-\mathrm{Pb}$ monazite geochronology is preferable for determining the crystallisation ages of Precambrian 
low-temperature, peraluminous leucocratic granites for the following reasons: (1) new monazite growth occurs readily at a range of $\mathrm{P}-\mathrm{T}$ conditions remaining robust over time with a closure temperature of $720-750{ }^{\circ} \mathrm{C}$ (Copeland et al. 1988); (2) monazite contains high $\mathrm{U}$ and $\mathrm{Th}$ and incorporates minor common $\mathrm{Pb}$ (Townsend et al. 2001); (3) monazite, unlike zircon, generally does not contain inherited cores and is immune from radiogenic $\mathrm{Pb}$ loss at low temperatures (Grosse et al. 2009); (4) occurrences of inherited monazite, although common in Tertiary S-type granites (Copeland et al. 1988), are uncommon in Precambrian rocks (Parrish 1990); and (5) magmatic monazite is one of the most common accessory mineral in granites and is abundant in peraluminous compositions (Bea 1996; Montel 1993; Rapp and Watson 1986). Our study has also resolved the duration of two generations of magmatism: in one instance emplacement occurred over a much shorter time interval ( $\sim 30$ million years) implying a higher rate of magma production than previously thought, and second, whereas purely leucocratic granites and pegmatites of the Thirty-Three Supersuite span a remarkably long duration of c. 130 million years implying a very low rate of magma generation. Finally, the use of monazite geochronology was able to narrow the possible window of magmatism to a discrete reworking event significantly reducing the time span previously thought.

Acknowledgements We thank Simon Johnson and Ian Fitzsimons for their critical and insightful reviews. Zedenka Martelli kindly provided assistance with monazite identification and picking. This manuscript was significantly improved by valuable comments received from an anonymous reviewer. U- Th- $\mathrm{Pb}$ measurements were conducted using the SHRIMP ion microprobes at the John de Laeter Centre at Curtin University. Michael Wingate publishes with permission of the Director of the Geological Survey of Western Australia. Australian Research Council Linkage Grant LP130100922 and the Geological Survey of Western Australia (through the Exploration Incentive Scheme) funded this $\mathrm{PhD}$ Project.

Open Access This article is distributed under the terms of the Creative Commons Attribution 4.0 International License (http://creativecommons.org/licenses/by/4.0/), which permits unrestricted use, distribution, and reproduction in any medium, provided you give appropriate credit to the original author(s) and the source, provide a link to the Creative Commons license, and indicate if changes were made.

\section{References}

Ayres M, Harris N, Vance D (1997) Possible constraints on anatectic melt residence times from accessory mineral dissolution rates; an example from Himalayan leucogranites. Miner Mag 61:29-36

Bea F (1996) Residence of REE, Y, Th and U in granites and crustal protoliths; implications for the chemistry of crustal melts. J Petrol 37:521-552

Bea F, Montero P, González-Lodeiro F, Talavera C (2007) Zircon inheritance reveals exceptionally fast crustal magma generation processes in Central iberia during the Cambro-Ordovician. J Petrol 48:2327-2339

Bodorkos S, Wingate MTD (2007) The contribution of geochronolgy to GSWA's mapping programs: current perspectives and future directions. Geol Surv West Aust 2:10-11

Boehnke P, Watson EB, Trail D, Harrison TM, Schmitt AK (2013) Zircon saturation re-revisited. Chem Geol 351:324-334

Broska I, Petrik I, Williams CT (2000) Coexisting monazite and allanite in peraluminous granitoids of the Tribeč Mountains, Western Carpathians. Am Miner 85:22-32

Brown M (1994) The generation, segregation, ascent and emplacement of granite magma: the migmatite-to-crustally-derived granite connection in thickened orogens. Earth Sci Rev 36:83-130

Budzyń B, Harlov DE, Williams ML, Jercinovic MJ (2011) Experimental determination of stability relations between monazite, fluorapatite, allanite, and REE-epidote as a function of pressure, temperature, and fluid composition. Am Miner 96:1547-1567

Copeland P, Parrish RR, Harrison TM (1988) Identification of inherited radiogenic $\mathrm{Pb}$ in monazite and its implications for $\mathrm{U}-\mathrm{Pb}$ systematics. Nature 333:760-763

Crowley JL, Brown RL, Gervais F, Gibson HD (2008) Assessing Inheritance of Zircon and Monazite in Granitic Rocks from the Monashee Complex, Canadian Cordillera. J Petrol 49:1915-1929

Culver KE (2001) Structure, metamorphism and geochronology of the northern margin of the Gurun Gutta Granite, Central Gascoyne Complex, Western Australia. Curtin University of Technology, Perth BSc. (Hons) thesis (unpublished)

Finger F, Broska I, Roberts MP, Schermaier A (1998) Replacement of primary monazite by apatite-allanite-epidote coronas in an amphibolite facies granite gneiss from the eastern Alps. Am Miner 83:248-258

Fletcher IR, McNaughton NJ, Davis WJ, Rasmussen B (2010) Matrix effects and calibration limitations in ion probe $\mathrm{U}-\mathrm{Pb}$ and $\mathrm{Th}-\mathrm{Pb}$ dating of monazite. Chem Geol 270:31-44

Gao L-E, Zeng L, Asimow PD (2017) Contrasting geochemical signatures of fluid-absent versus fluid-fluxed melting of muscovite in metasedimentary sources: the Himalayan leucogranites. Geology 45:39-42

Gilotti JA, McClelland WC (2005) Leucogranites and the time of extension in the East Greenland Caledonides. J Geol 113:399-417

Grosse P, Söllner F, Báez MA, Toselli AJ, Rossi JN, de la Rosa JD (2009) Lower Carboniferous post-orogenic granites in centraleastern Sierra de Velasco, Sierras Pampeanas, Argentina: U-Pb monazite geochronology, geochemistry and $\mathrm{Sr}-\mathrm{Nd}$ isotopes. Int J Earth Sci 98:1001-1025

GSWA (2016a) 1:500 000 State interpreted bedrock geology of Western Australia, 2016: Geological Survey of Western Australia, digital data layer. www.dmp.wa.gov.au/geoview

GSWA (2016b) Compilation of geochronology information, 2016 update, digital data product. www.dmp.wa.gov.au/geoview

Harrison MT, Grove M, McKeegan KD, Coath CD, Lovera OM, Fort PL (1999) Origin and episodic emplacement of the Manaslu intrusive complex, central Himalaya. J Petrol 40:3-19

Johnson SP et al (2011) Two collisions, two sutures: punctuated pre-1950Ma assembly of the West Australian Craton during the Ophthalmian and Glenburgh Orogenies. Precambr Res 189:239-262

Johnson SP, Korhonen FJ, Kirkland CL, Cliff JA, Belousova EA, Sheppard S (2017) An isotopic perspective on growth and differentiation of Proterozoic orogenic crust: from subduction magmatism to cratonization. Lithos 268-271:76-86

Kemp AIS, Hawkesworth CJ (2003) 3.11—granitic perspectives on the generation and secular evolution of the continental crust A2-Holland, Heinrich D. In: Turekian KK (ed) Treatise on geochemistry. Pergamon, Oxford, pp 349-410 
Kirkland CL, Wingate MTD (2012) Reading deep time: radiogenic isotopic geochronology. Geological Survey of Western Australia 2012, 15

Kirkland CL, Wingate MTD, Bodorkos S, Sheppard S (2009) 183287: Granite, Perseverance Well; Geochronology Record 756. Geological Survey of Western Australia

Korhonen FJ et al. (2015) Pressure-temperature-time evolution of the Mutherbukin Tectonic event, Capricorn Orogen. Geological Survey of Western Australia 146

Kusiak MA, Williams IS, Dunkley DJ, Konečny P, Słaby E, Martin H (2014) Monazite to the rescue: U-Th-Pb dating of the intrusive history of the composite Karkonosze pluton, Bohemian Massif. Chem Geol 364:76-92

Le Maitre RW (1989) A classification of the igneous rocks and glossary of terms. Blackwell, Oxford, p 193

Lee DE, Dodge FCW (1964) Accessory minerals in some granitic rocks in California and Nevada as a function of calcium content. Am Miner 49:1660-1669

Ludwig KR (2009) Squid 2.50, a user's manual Berkeley geochronology centre special publication

Miller CF, Mittlefehldt DW (1982) Depletion of light rare-earth elements in felsic magmas. Geology 10:129-133

Miller CF, Meschter McDowell S, Mapes RW (2003) Hot and cold granites? Implications of zircon saturation temperatures and preservation of inheritance. Geology (Boulder) 31:529-532

Montel J-M (1993) A model for monazite/melt equilibrium and application to the generation of granitic magmas. Chem Geol 110:127-146

Nelson DR (1998) 142855: porphyritic monzogranite, Anderson Well; Geochronology Record 371: Geological Survey of Western Australia

Nelson DR (2000) 139466: foliated biotite-muscovite-garnet granodiorite, Erong Homestead; Geochronology Record 427: Geological Survey of Western Australia

Nelson DR (2004) 169092: biotite-muscovite monzogranite, Red Rock Bore; Geochronology Record 103: Geological Survey of Western Australia

Occhipinti SA, Reddy SM (2009) Neoproterozoic reworking of the Palaeoproterozoic Capricorn Orogen of Western Australia and implications for the amalgamation of Rodinia. Geol Soc Lond Spec Publ 327:445-456

Occhipinti SA, Sheppard S, Myers JS, Tyler IM, Nelson DR (2001) Archaean and Palaeoproterozoic geology of the Narryer Terrane (Yilgarn Craton) and the southern Gascoyne Complex (Capricorn Orogen), Western Australia-a field guide. Geological Survey of Western Australia 2001, 8

Occhipinti SA, Sheppard S, Passchier C, Tyler IM, Nelson DR (2004) Palaeoproterozoic crustal accretion and collision in the southern Capricorn Orogen: the Glenburgh Orogeny. Precambr Res 128:237-255

Parrish RR (1990) U-Pb dating of monazite and its application to geological problems Canadian. J Earth Sci 27:1431-1450

Parrish RR, Tirrul R (1989) U-Pb age of the Baltoro granite, northwest Himalaya, and implications for monazite U-Pb systematics. Geology 17:1076-1079

Patiño Douce AE, Harris N (1998) Experimental constraints on Himalayan anatexis. J Petrol 39:689-710

Poitrasson F, Chenery S, Bland DJ (1996) Contrasted monazite hydrothermal alteration mechanisms and their geochemical implications. Earth Planet Sci Lett 145:79-96

Rapp RP, Watson EB (1986) Monazite solubility and dissolution kinetics: implications for the thorium and light rare earth chemistry of felsic magmas. Contrib Miner Petrol 94:304-316
Rasmussen B, Fletcher IR, Sheppard S (2005) Isotopic dating of the migration of a low-grade metamorphic front during orogenesis. Geology 33:773-776

Scaillet B, Pichavant M, Roux J (1995) Experimental crystallization of leucogranite magmas. J Petrol 36:663-705

Scaillet B, Holtz F, Pichavant M (2016) Experimental constraints on the formation of silicic magmas. Elements 12:109-114

Schärer U, Xu RH, Allègre CJ (1986) U-(Th)-Pb systematics and ages of Himalayan leucogranites, South Tibet. Earth Planet Sci Lett $77: 35-48$

Scott JM, Palin JM, Cooper AF, Sagar MW, Allibone AH, Tulloch AJ (2011) From richer to poorer: zircon inheritance in Pomona Island Granite, New Zealand. Contrib Miner Petrol 161:667-681

Sheppard S, Occhipinti SA, Nelson DR (2005) Intracontinental reworking in the Capricorn Orogen, Western Australia: the 1680-1620 Ma Mangaroon Orogeny. Aust J Earth Sci $52: 443-460$

Sheppard S, Rasmussen B, Muhling JR, Farrell TR, Fletcher IR (2007) Grenvillian-aged orogenesis in the Palaeoproterozoic Gascoyne Complex, Western Australia: 1030-950 Ma reworking of the Proterozoic Capricorn Orogen. J Metamorph Geol 25:477-494

Sheppard S, Bodorkos S, Johnson SP, Wingate MTD, Kirkland CL (2010a) The paleoproterozoic capricorn orogeny: intracontinental reworking not continent-continent collision. Geological Survey of Western Australia 108

Sheppard S, Johnson SP, Wingate MTD, Kirkland CL, Pirajno F (2010b) Explanatory notes for the Gascoyne Province. Geological Survey of Western Australia 1:100 000 Explanatory Notes

Townsend KJ, Miller CF, D'Andrea JL, Ayers JC, Harrison TM, Coath CD (2001) Low temperature replacement of monazite in the Ireteba granite, Southern Nevada: geochronological implications. Chem Geol 172:95-112

Watson EB, Harrison TM (1983) Zircon saturation revisited: temperature and composition effects in a variety of crustal magma types. Earth Planet Sci Lett 64:295-304

Williams IS, Compston W, Chappell BW (1983) Zircon and Monazite $\mathrm{U}-\mathrm{Pb}$ Systems and the Histories of I-Type Magmas, Berridale Batholith, Australia. J Petrology 24(1):76-97

Wingate M, Lu Y (2016) Introduction to geochronology information released in 2014. Geological Survey of Western Australia

Wingate M, Kirkland C, Sheppard S, Johnson S (2010a) 185945: pegmatite lenses in metamonzogranite, Yinnetharra Homestead; Geochronology Record 901. Geological Survey of Western Australia

Wingate M, Kirkland C, Sheppard S, Johnson S (2010b) 185946: pegmatite dyke, Yinnetharra Homestead; Geochronology Record 902. Geological Survey of Western Australia

Wingate M, Kirkland C, Johnson S (2011) 190667: granite pegmatite, Camel Hill; Geochronology Record 1003. Geological Survey of Western Australia

Wingate MTD, Lu Y, Johnson SP (in press) 183288: biotite-tourmaline monzogranite, Perseverance Well; Geochronology Record 1352. Geological Survey of Western Australia

Zen E (1986) Aluminum enrichment in silicate melts by fractional crystallization: some mineralogic and petrographic constraints. J Petrol 27:1095-1117

Zi J-W et al (2015) In situ U-Pb geochronology of xenotime and monazite from the Abra polymetallic deposit in the Capricorn Orogen, Australia: dating hydrothermal mineralization and fluid flow in a long-lived crustal structure. Precambr Res 260:91-112 